Waldemar Kowalski

Uniwersytet Jana Kochanowskiego w Kielcach

\title{
„To jest owczarnia onego Dobrego Pasterza”. Pojęcie „prawdziwego” Kościoła w polskich szesnastowiecznych katechizmach
}

Artykuł ukazuje, jak pojmowali i tłumaczyli pojęcie Kościoła autorzy polskich katolickich i ewangelickich katechizmów XVI w. Zgodnie z programem Trydentu Kościół katolicki przedstawiany jest jako kontynuator nauki apostołów, silny autorytetem papieża, następcy Piotra, oraz jednością wiary, o której prawdziwości przekonują cuda. Teolodzy protestanccy uczą o kościele widzialnym, który istnieje wszędzie tam, gdzie przepowiadane jest czyste Słowo Boże, sakramenty administrowane są zaś zgodnie z Ewangelią. Razem z Kościołem widzialnym istnieje Kościół powszechny niewidzialny. Łączy on wszystkich idących za Chrystusem, który jest jedyną głową swego Kościoła.

The paper focuses on the way in which the authors of Polish Catholic and Evangelical catechisms of the $16^{\text {th }}$ century understood and explained of the idea of the Church. According to the decrees of the Council of Trent, the Catholic Church was presented as the continuator of the teachings of the Apostles, with its power deriving from the authority of the Pope, the successor of Peter, and unity of faith confirmed by miracles. Protestant theologists preach about the visible church, which exists wherever the pure Word of God is preached, and claim that sacraments are administered in accordance with the Gospel. The universal invisible Church exists alongside the visible Church. It connects every person following the Christ, who is the only head of his Church.

Słow a kluczowe: Kościół, polsko-litewska Rzeczpospolita, katechizm, nauczanie religijne, reformacja, reforma trydencka

Ke ywo rds: church, Polish-Lithuanian Commonwealth, catechism, religious teaching, Reformation, Trent reform 
W podzielonej wyznaniowo szesnastowiecznej Europie kwestia przynależności do właściwego, to jest „prawdziwego”, Kościoła, należała do zagadnień fundamentalnych ${ }^{1}$. Teolodzy katoliccy i ewangeliccy zgodnie twierdzili, że słuszny wybór prowadził do zbawienia, choć go nie gwarantował ${ }^{2}$. Skłaniało to wielu chrześcijan do konfrontacji własnych doświadczeń religijnych z licznymi zachętami do porzucenia dotychczasowych współwyznawców. Dla polskich chrześcijan decydowanie się na taki krok oznaczało na ogół występowanie z Kościoła rzymskokatolickiego i przyłączanie się do protestanckich wspólnot kontestujących „starą wiarę”. Rozważanie w sumieniu swego miejsca we wspólnocie Kościoła nie musiało jednak prowadzić do konwersji, a przeciwnie - mogło umacniać w dotychczasowym wyznaniu ${ }^{3}$. W pobudzaniu oraz wyjaśnianiu takich wątpliwości dużą rolę odgrywali przewodnicy duchowni. Dla nich właśnie oraz z myślą o świeckich powstawały katechizmy zaznajamiające $\mathrm{z}$ rudymentami wiary ${ }^{4}$.

Celem piszącego te słowa jest prześledzenie argumentów, na których opierano przekonanie o prawdzie i fałszu wyznawanej oraz

1 Taką opinię wyraziła m.in. S. E. Schreiner, Church, w: The Oxford Encyclopedia of the Reformation, vol. 1, ed. by H. J. Hillebrand, Oxford-New York 1996, s. 323.

2 Eadem, Are You Alone Wise? The Search for Certainty in the Early Modern Era, Oxford-New York 2011, s. 37-77.

3 Spośród bogatej literatury poświęconej okolicznościom i konsekwencjom konwersji religijnych w średniowiecznej i wczesnonowożytnej Europie pesymistyczną oceną płynących stąd skutków wyróżnia się rozprawa A. Pettegree, Reformation and the Culture of Persuasion, Cambridge 2007, s. 211-217. Autor zwraca uwage m.in. na częstą konieczność zerwania dotychczasowych więzi społecznych, trudności adaptacyjne w nowym środowisku oraz wynikające stąd rozczarowania.

${ }^{4} \mathrm{Z}$ chronologią powstawania i zakresem rzeczowym publikowanych w Polsce katolickich i protestanckich katechizmów zaznajamia D. Kuźmina, Katechizmy w Rzeczypospolitej XVI i poczatku XVII wieku, Warszawa 2002. O katechizmach katolickich zob.: J. Z. Słowiński, Katechizmy katolickie w jezyku polskim od XVI do XVIII wieku, Lublin 2005; W. Pawlik, Katechizmy w Rzeczypospolitej od XVI do XVIII wieku, Lublin 2010. Na temat katechizmów ewangelickich por.: M. Korzo, W sprawie jednego z XVI-wiecznych katechizmów kalwińskich $w$ Rzeczpospolitej, OiRwP, 52, 2007, s. 177-198; eadem, Przyczynek do roli druków bazylejskich w XVI-wiecznym piśmiennictwie ewangelickim Wielkiego Księstwa Litewskiego, OiRwP, 55, 2011, s. 7-25; poza tym por. T. Reroń, Katechizmy w dobie Soboru Trydenckiego, „Wrocławski Przegląd Teologiczny”, 7, 1999, s. 129-143. L. Palmer Wandel (Reading Catechisms, Teaching Religion, Leiden-Boston 2015) zwraca uwagę na jedność nauczania religijnego poprzez słowo pisane, mówione oraz ikonografię. 
potępianej doktryny o Kościele. Zamiar ten prowokuje także do postawienia pytania o to, czy definiowana konfesyjnie odrębność eklezjalna wykluczała jakiekolwiek poczucie wspólnoty podzielonych chrześcijan. Ze względu na swą deklaratywność i relatywnie szeroki zasięg oddziaływania katechizmy wydają się być reprezentatywną podstawą dla tak określonych dociekań. „Polskie katechizmy", wspomniane w tytule tego artykułu, to dzieła polskich autorów oraz adaptatorów, pisane z myślą o czytelnikach posługujących się w codziennej komunikacji językiem polskim, ale prawdopodobnie znających też łacinę.

W Kościele katolickim przełomu średniowiecza i wczesnej nowożytności podstawową formą powszechnej edukacji religijnej było nie tyle systematyczne kaznodziejstwo, ile raczej przekazywanie wiernym elementarnej wiedzy. Choć na bardziej pogłębioną refleksję religijną zdobywała się raczej mniejszość duchownych i świeckich, znajomość podstaw wiary uznać można za powszechną . Przemiany społeczne w Kościele XVI w. powodują rozwój katechezy „intelektualnej i dogmatycznej" - świadectwem tego są kompendia luterańskie, kalwińskie oraz teksty broniące katolickiej ortodoksji ${ }^{6}$. Ze źródeł postulatywnych powstających pod wpływem reform trydenckich, jak np. akta synodalne, jasno wynika waga, jaką do katechizmów przywiązywali ówcześni hierarchowie ${ }^{7}$. Niemniej jednak praktyczne znaczenie w szerszej skali takich pomocy w edukacji świeckich i ich pasterzy w Polsce XVI stulecia pozostaje poza systematycznym oglądem z powodu braku źródeł. Obraz reformy rozpoczętej w rozległej diecezji krakowskiej przez kardynała Jerzego Radziwiłła w 1593 r. i kontynuowanej przez jego następców w pierwszych dekadach kolejnego wieku szczegółowo ukazuje trudne początki systematycznej pracy duszpasterskiej. Kardynał nakazywał duchownym, aby wspomagali się Katechizmem rzymskim, po inne zaś tego typu pomoce sięgali,

5 Argumentów za taką oceną dostarczają m.in.: K. Bracha, Nauczanie kaznodziejskie w Polsce późnego średniowiecza. Sermones dominicales et festivales z tzw. kolekcji Piotra z Mitostawia, Kielce 2007; S. Bylina, Chrystianizacja wsi polskiej u schytku średniowiecza, Warszawa 2002; J. Kracik, Przeciw Reformacji, w: Kościót krakowski w tysiacleciu, Kraków 2000, s. 178-250; T. Wiślicz, Zarobić na duszne zbawienie. Religijność chtopów matopolskich od potowy XVI do końca XVIII wieku, Warszawa 2001, s. 28-38.

${ }^{6}$ Por. P. Chaunu, Czas reform. Historia religii i cywilizacji (1250-1550), tł. J. Grosfeld, Warszawa 1989, s. 164-165.

7 Ostatnio pisała o tym M. Korzo, Polski przektad katechizmu Jakuba Ledesmy TJ i jego wptyw na tradycje unicka $w$ XVII w., OiRwP, 47, 2004, s. 149-150. 
kierując się indywidualnymi możliwościami. Stan poświadczony dla diecezji krakowskiej, gdzie księża posługiwali się przedstawionymi niżej kompendiami polskich autorów, nie musi być jednak reprezentatywny dla innych terenów kościelnej prowincji gnieźnieńskiej ${ }^{8}$. Nie ma też powodów, aby wątpić w przekonanie pastorów ewangelickich o potrzebie korzystania z takich źródeł ${ }^{9}$.

Analizą objęto przede wszystkim kompendia adresowane ad parochos, wykorzystywane w cura animarum, a jednocześnie przystępnie tłumaczące podstawy wiary i prawa Bożego czytelnikowi czy słuchaczowi o rudymentarnej świadomości swego miejsca w Kościele. Z tych względów w zasadzie pominięto tu katechizm Stanisława Hozjusza Confessio fidei catholicae Christiana, opublikowany po raz pierwszy w Krakowie w 1553 r., a wkrótce powszechnie przyjęty w całym Kościele jako podręcznik teologii pozytywno-kontrowersyjnej ${ }^{10}$. Pierwsze polskie tłumaczenie Katechizmu rzymskiego, ogłoszone w 1568 r., nie spełniło zapewne pokładanych w nim oczekiwań, stąd też nowy polski przekład, który ukazał się jednak dopiero w roku $1603^{11}$. Trudno więc mówić o istotnym wpływie tego dzieła na nauczanie polskiego Kościoła przed początkiem XVII stulecia. Nie wszystkie też ważne w szesnastowiecznej Polsce kompendia wiedzy religijnej, pisane z myślą o parafialnych duszpasterzach, omawiały interesujące nas zagadnienie. Pomija je m.in. zasłużony dla walki z różnowierstwem i odnowy życia religijnego w Polsce współpracownik Hozjusza Marcin Kromer, autor Catecheses, to jest napominania $i$ nauki

8 Szerzej na ten temat zob.: H. E. Wyczawski, Biblioteki parafialne $w$ diecezji krakowskiej u schytku XVI wieku, „Polonia Sacra”, 7, 1955, s. 44; idem, Studia nad wewnętrznymi dziejami Kościota w Matopolsce na schytku XVI wieku, „Prawo Kanoniczne”, 7, 1964, s. 109; R. Kuśmierczyk, Problematyka Listu pasterskiego kard. Jerzego Radziwitta z roku 1593, „Nasza Przeszłość”, 100, 2003, s. 236-237. A. Rojewski (Formacja duchowieństwa archidiakonatu dobrzyńskiego $w$ latach 1597-1609 i jej wptyw na przyjęcie posoborowej liturgii, „Studia Płockie”, 4, 1976, s. 34-50) zauważa, że nie rekomendowano duchownym podręczników polskich autorów i brak dowodów, aby takie posiadali.

9 Katechizmowe rudymenty wiary leżały u podstaw formacji teologicznej i pobożności Marcina Lutra, który stale podkreślał doniosłość takiego nauczania, zob. M. J. Haemig, The Influence of the Genres of Exegetical Instruction, Preaching and Catechesis on Luther, w: The Oxford Handbook of Martin Luther's Theology, ed. by R. Kolb, I. Dingel, L. Batka, Oxford 2014, s. 455-460.

10 Zalecany był on jako pomoc w duszpasterstwie, por. A. Skolimowska, Confessio fidei Hozjusza jako podstawa katechizacji wiernych w Hiszpańskich Niderlandach, „Studia Warmińskie”, 43, 2006, s. 273-275.

11 J. Z. Słowiński, op. cit., s. 93-99. 
każdemu człowiekowi chrześcijańskiemu $(1570)^{12}$. Do dzieci oraz ludzi prostych adresował swój apologetyczno-dogmatyczny Katechizm maty Roberto Bellarmino. Ten „Achilles przeciw heretykom”, jak napisano w Krakowie w 1616 r., spopularyzowany został w Polsce dopiero po roku $1606^{13}$. Uwzględnione tu katechizmy ewangelickie powstawały pod wpływem nauki Lutra oraz teologów południowoniemieckich i szwajcarskich. Zasygnalizowane zostały również stosowne poglądy braci czeskich. Starano się więc uwzględnić kompendia krążące pośród tych chrześcijan Rzeczypospolitej, którzy zerwali z „papieżem, synem zatracenia"14. Ówczesne ewangelickie katechizmy łączyły wykład podstaw wiary z modlitewnikiem i kancjonałem ${ }^{15}$. Stawianie jednoznacznych wniosków w oparciu o zamieszczane tam pieśni istotnie ogranicza brak kompleksowych, porównawczych analiz tych kolekcji ${ }^{16}$.

Eklezjologia, którą poznawali wierni polskiego Kościoła późnego średniowiecza, rozróżniała za Augustynem trzy rodzaje domów Bożych: dom materialny, czyli budynek świątyni, dom duchowy, który stanowiła wspólnota wszystkich wiernych, oraz dom niebieski, zbudowany z żywych kamieni, to jest dusz świętych i aniołów. W Kościele-wspólnocie wiernych kamieniami są wszyscy prawdziwie wierzący, kolumnami - święci doktorzy i kaznodzieje, fundamentem - żywa wiara, ścianami - nadzieja, podłogą zaś skrywającą wszystkie grzechy - miłość. Jako Kościół niebiański interpretowano też niewidzialny Kościół zbawionych. Za Hugonem od św. Wiktora powtarzano, że Kościół gromadzi wiernych w stanie łaski i w stanie grzechu. Poza Kościołem pozostawali heretycy - fałszywi prorocy, moce diabelskie, poganie i tyrani ${ }^{17}$.

Potrzebę tłumaczenia wiernym, czym jest społeczność Kościoła dostrzegali teologowie i kaznodzieje wszystkich głównych nurtów

12 O druku tym W. Pawlik, op. cit., s. 96-97.

13 Ibidem, s. 104-105; A. Kiciński, Kierunki rozwoju katechizmów katolickich, „Roczniki Pastoralno-Katechetyczne”, 59, 2012, s. 128; L. Kromer, Przedmowa, w: L. Lessius, Narada, której wiary trzymać się mamy, Kraków 1616 (BUW, sygn. SD XVII.3.3776), k. nlb.

14 Catholici et sectarii concertatio, Cracoviae 1569 (BK, sygn. Cim. O. 184), k. C ${ }_{\mathrm{iv}}$.

15 A. Kawecka, Kancjonaty protestanckie na Litwie w w. XVI, „Reformacja w Polsce”, 4, 1926, s. 128 .

16 Mimo ważnych studiów szczegółowych, m.in.: P. Fijałkowski, Kancjonat Piotra Artomiusza z 1620 r., OiRwP, 44, 2000, s. 129-148; K. Smolarek, Piotr Artomiusz $i$ jego kancjonat toruński z końca XVI wieku, „Rocznik Toruński”, 41, 2014, s. 169-186.

17 Szerzej zob. K. Bracha, op. cit., s. 289-293. 
zachodniego chrześcijaństwa. Spoczywający na klerze obowiązek systematycznego roztrząsania rudymentów obejmował m.in. objaśnianie deklaracji wiary w „jeden, święty, powszechny i apostolski Kościół”, będącej częścią Symbolu apostolskiego ${ }^{18}$. Nie jest więc zaskoczeniem, że pojęcie „prawdziwego" Kościoła omawiane jest w szesnastowiecznych katechizmach właśnie przy okazji objaśniania tekstu Credo. Zagadnienie to bez wątpienia pojawiało się w rozważaniach średniowiecznych duszpasterzy, o czym świadczą zabytki sztuki i traktaty ${ }^{19}$. Ojcowie soboru trydenckiego, choć akcentowali konieczność powszechnej edukacji wiernych, ograniczyli się jedynie do ogólnego stwierdzenia, że nauczać należy lud „tego, co dla wszystkich konieczne jest do zbawienia" ${ }^{20}$. Akcentowali zaś przede wszystkim moralny aspekt tej edukacji. Jednak wybitni polscy duszpasterze epoki, jak np. Jakub Wujek SI, świadomi byli potrzeby wyjaśniania, czym jest Kościół. Wujek jego cechy ujął, w zgodzie z Bellarmino i Stapeltonem, jako: jedność wiary i jedność pasterza, wspierane przez powagę wieków, następstwo w hierarchii, powszechność na ziemi, wywyższenie Kościoła, moc wewnętrzna oraz cuda ${ }^{21}$. Widać tu wpływ Tridentinum, które zerwało z dążeniami koncyliarystycznymi w Kościele ${ }^{22}$.

Dla poglądów obozu różnowierczego reprezentatywne jest stanowisko Pawła Gilowskiego, jednego z przywódców małopolskiego Zboru większego czasów Zgody sandomierskiej ${ }^{23}$. Według tego autora każdy młody człowiek powinien znać Boże przykazania, Wyznanie Wiary, Modlitwę Pańską, a także „prawdziwy Kościół krześciański i dobrze rozumieć o sakramenciech"24. Wiedzę tę młodzież zyskuje, aktywnie uczestnicząc w życiu zboru. Stanowisko takie nie zaskakuje,

18 J. Wolny, Z dziejów katechezy, w: Dzieje teologii katolickiej w Polsce, t. 1: Sredniowiecze, Lublin 1974, s. 191-206.

19 Zob. A. Dąbrówka, Treści religijne w średniowiecznych podręcznikach i lekturach szkolnych, w: Animarum cultura. Studia nad kultura religijna na ziemiach polskich $w$ średniowieczu, t. 1: Stosunki kościelno-publiczne, red. H. Manikowska, W. Brojer, Warszawa 2008 (Colloquia Mediaevalia Varsoviensia, t. 4), s. 474.

20 Dokumenty soborów powszechnych. Tekst tacinski i polski, t. 4: 1511-1870: Lateran, Trydent, Watykan I, oprac. A. Baron, H. Pietras, Kraków 2005, s. 246-247.

21 F. Bracha, Jakub Wujek jako dogmatyk, „Polonia Sacra”, 3/1-2, 1950, s. 131, $151-156$.

22 O tym szerzej zob. S. Świeżawski, Eklezjologia późnośredniowieczna na rozdrożu, Kraków 1990, s. 49-77, 202-206.

23 S. Szczotka, Gilowski Pawet, PSB, 7, 1948-1958, s. 471-472.

24 P. Gilowski, Wyktad katechizmu Kościota krześcijańskiego, Kraków 1579 (BO, sygn. XVI 2801), k. 114rec.-114ver. 
bowiem nauczanie zgodne z Dobrą Nowiną, właściwe sprawowanie sakramentów (oraz dyscyplina) to fundament ewangelickiej eklezjologii. Razem z tak definiowanym widzialnym Kościołem istnieje powszechny Kościół wewnętrzny, niewidzialny, z którym jedność wyznajemy w Credo ${ }^{25}$.

Zasygnalizowane tu zagadnienia omawiam najpierw na podstawie zabytków katolickich, a następnie ewangelickich. Są to teksty na ogół zwięzłe, lecz nie brak wśród nich utworów obszernie referujących podstawy wiary, stąd też zróżnicowany objętościowo komentarz interesujących nas zagadnień.

Źródła katolickie

Stosunkowo niewiele miejsca poświęca Kościołowi Wojciech Nowopolczyk (Albertus Novicampianus), profesor Akademii Krakowskiej, teolog-polemista ${ }^{26}$. Zwraca on uwagę, że ustanowiony jest na Słowie Bożym zapisanym w Piśmie Świętym, a urząd nauczycielski (magisterium) Kościoła rozróżnia prawdziwą i fałszywą naukę, dlatego, za św. Pawłem, przypomina (powołując się na 1 Tym 3, 15): „ecclesia columna et firmamentum veritatis”27. Kościół wiedziony Duchem

$25 \mathrm{Ku}$ takiemu określaniu widzialnego Kościoła skłaniało się wielu wybitnych teologów wczesnego etapu europejskiej reformacji. Szerzej na ten temat zob. przede wszystkim: P. D. L. Avis, The Church in the Theology of the Reformers, Eugene (OR) 2002; idem, Luther's Theology of the Church, "Churchman”, 97, 1983, s. 104-111; D. P. Daniel, Luther on the Church, w: The Oxford Handbook of Martin Luther's Theology, s. 333-335; E. Campi, Calvin's Understanding of the Church, „Reformed World”, 57, 2007, s. 291-292; R. M. Kingdon, The Church. Ideology or Institution, „Church History”, 50, 1981, s. 85-86; H. Kowalska, 'Przejrzani i wybrani'. O Kościele na Zgodzie Sandomierskiej budowanym, w: Kultura polska a kultura europejska. Prace ofiarowane Januszowi Tazbirowi w sześćdziesiąta rocznice urodzin, red. M. Bogucka, J. Kowecki, Warszawa 1987, s. 205 -213. Pogląd taki nie był wszakże jedyny, gdyż inaczej definiował Kościół m. in. Jan Łaski w konfesji swego londyńskiego zboru (1551), por.: J. Becker, Migration and Confession among Sixteenth-Century Western European Reformed Christians, „Reformation and Renaissance Review”, 13, 2011, s. 14; H. Kowalska-Kossobudzka, Jana Easkiego pojęcie Kościota, OiRwP, 10, 1965, s. 81-101.

26 Zob. H. E. Wyczawski, Nowopolczyk Wojciech, w: SPTK, t. 3, red. H. E. Wyczawski, Warszawa 1983, s. 233-234; J. Tyrawa, Nowopolczyk, Nowopolski, Novicampianus, Wojciech, w: Encyklopedia katolicka, t. 14, red. E. Gigilewicz et al., Lublin 2010, szp. 77.

27 A. Novicampianus, Scopus biblicus Veteris et Novi Testamenti, cum annotationibus summam doctrinae Christianae complectentibus, Antverpiae 1559 (BO, sygn. XVI 0.36), s. 168-170 (tu s. 168); pierwodruk w Krakowie, w 1553 r. 
urasta $\mathrm{w}$ jego interpretacji do rangi najwyższego autorytetu ustalającego prawa w kwestiach wiary. Argumenty dla zbawczej roli Kościoła znajduje w biblijnej tradycji, uwagi te zaś zamieszcza w komentarzu dotyczącym prawa.

Otwarcie polemiczny, choć nieagresywny charakter mają opublikowane w 1558 r. wywody innego krakowskiego akademika, Antoniego z Napachania ${ }^{28}$. Oskarża on „heretyków”, że, wbrew obietnicy Chrystusa: „Oto ja jestem z wami wszystkich dni, aż do skończenia świata” (Mt 28, 20), próbują zawłaszczyć Syna Bożego do swych kościołów. Ostrzega więc czytelników: „Tedy jeśliby wam kto mówił: oto tu jest Christus albo ondzie, nie wierzcie" ${ }^{29}$; Lutra oraz innych protestantów określa mianem "fałszywych Christów” ${ }^{30}$. Powtarza też jeden z najczęściej przytaczanych przez katolickich polemistów antyprotestancki argument, zgodnie z którym spory między teologami ewangelickimi zaświadczały o braku jedności w Duchu Świętym, a co za tym idzie wspólnoty te nie miały podstawowej właściwości eklezjalnej ${ }^{31}$.

Kościół jest jeden święty, powszechny („pospolity”) i apostolski, utożsamiony $\mathrm{z}$ „zebraniem wiernych”, czyli zborem ${ }^{32}$, a „dzierży” go Duch Święty. Wierni, zgodnie z nauczaniem św. Pawła, są duchowym ciałem Chrystusowym, Zbawiciel zaś - głową tego ciała (Ef 1, 22-23), o czym przypomina Credo powtarzane podczas mszy. Wymienione wyżej cechy Kościoła warunkują również nakaz zachowania w nim jedności, do czego także zachęca apostoł (1 Kor 10-13). O świętości Kościoła decyduje nie to, że składają się nań święci i sprawiedliwi,

28 Antoni z Napachania, Enchiridion to iest ksiaszki ręczne o nauce Chrześcianskiey, czego się Chrześciański cztowiek dzierżeć ma czasu ninieyszey rozności wiary, Kraków 1558 (BK, sygn. Cim. O. 169). O autorze zob.: H. E. Wyczawski, Antoni z Napachania, w: SPTK, t. 1, red. H. E. Wyczawski, Warszawa 1981, s. 59; M. Rechowicz, Antoni z Napachania, w: Encyklopedia katolicka, t. 1, red. F. Gryglewicz et al., Lublin 1995, szp. 665.

29 Antoni z Napachania, op. cit., k. 1rec.-1ver.

30 Ibidem, k. 1ver.

31 O stosownej polemice Hozjusza i Łaskiego oraz stanowisku tego ostatniego, reprezentatywnym dla ówczesnej eklezjologii ewangelickiej, zob. H. Kowalska-Kossobudzka, Wptyw Jana Easkiego na ksztattowanie się reformacyjnego Kościota w Matopolsce, w: Jan Easki 1499-1560. W pięćsetlecie urodzin, red. W. Kriegseisen, P. Salwa, Warszawa 2001, s. 26.

32 Termin 'zbór' jako synonim pojęcia Kościół (ecclesia) stosowany był przede wszystkim przez ewangelików, zob. I. Winiarska, Stownictwo religijne polskiego kalwinizmu od XVI do XVIII wieku (na tle terminologii katolickiej), Warszawa 2004, s. 276. 
ponieważ, jak podkreśla Antoni z Napachania, „pewna jest rzecz, iż w nim więcej jest grzesznych niż sprawiedliwych, więcej złych niż dobrych" 33 , dlatego przywołuje on także przypowieści o pszenicy i plewach (Łk 3, 16-17), kąkolu i pszenicy (Mt 13, 24-30) oraz o dniu sądu, owcach i kozłach (Mt 25, 31-34). Świętość Kościoła zależy od innego czynnika: „którzykolwiek są święci, jedno w tym Kościele są święci"34. Indywidualna świętość wiernych oznacza wolność od grzechu dzięki obmyciu krwią Chrystusa (tu autor przywołuje rozdział piąty z Listu do Efezjan, gdzie znajduje się przypomnienie o Chrystusie, który oczyścił swój Kościół wodą i słowem). Za św. Augustynem, twórcą Enchiridionu..., powtarza, że „wszyscy wierni pierwej byli zwani święci”, a Kościół „jest i pospolity, bo po wszystkim świecie rozszerzony" ${ }^{35}$. Taka wspólnota dochowuje posłuszeństwa biskupowi rzymskiemu jako namiestnikowi Piotra. Autor szeroko komentuje wybór Chrystusa związany z oparciem Kościoła na Piotrze - opoce (Mt 16, 18-19; J 21, 15-17) i podkreśla, że prymat papieża został potwierdzony przez autorytet Słowa Bożego. Poza tym, przypomina, Jezus szczególnie modlił się za Piotra, aby ufność jego nie ustała i aby była mu dana moc utwierdzania w wierze. Interpretację swą wspiera autorytetem ojców Kościoła, którzy właśnie tak rozumieli decyzję Chrystusa (ogólnie wspomina m.in. Augustyna, Hieronima, Ambrożego i Bedę).

Potrzebę utrzymania hierarchii uzasadnia też przykładami ze świata przyrody. Wskazuje pszczoły i żurawie, „które mają jednego wodza”36. Sięga też do Metafizyki Arystotelesa, mówiąc: „gdzie wiele panów, rząd dobry być nie może" ${ }^{37}$. Chrystus rządzi swym Kościołem, choć niewidocznie, korzystając z posługi kapłanów, a zatem, gdyby zabrakło papieża, „w Kościele będzie odszczepieństw, ile kapłanów"38. Wymienia w tym kontekście Lutra, Zwingliego, Kalwina i anabaptystów, gdyż ich wystąpienia wiązały się z wypowiedzeniem posłuszeństwa papieżowi i tym samym broni konieczności sukcesji apostolskiej. Przypomina, że nie wszystkie wskazania apostołów znamy z Pisma. Ich nauki, choć nieznane z kart Nowego Testamentu, przetrwały w ustnym przekazie, dlatego są pełnoprawnym

33 Antoni z Napachania, op. cit., k. 2ver.

34 Ibidem, k. 3rec.

35 Ibidem.

36 Ibidem, k. 5rec.

37 Ibidem.

38 Ibidem, k. 8rec. 
dziedzictwem Kościoła, szacunek zaś dlań wynika z Tradycji. Znaczenie Tradycji w życiu zbiorowości wiernych potwierdza Augustyn. Tam, gdzie nie ma sukcesji apostolskiej, nie ma Kościoła, jest zaś „synagoga szatańska”39. Za Tertulianem wzywa „heretyków”, aby pokazali, skąd pochodzi ich Kościół. Bez bliższej argumentacji zaleca naśladować postawę Erazma z Rotterdamu, nie zaś Lutra. Z tym ostatnim wchodzi w szczegółową polemikę eklezjologiczną. Podsumowując swój, miejscami niezbyt koherentny, ale obszernie argumentowany wywód, podkreśla, że o sile Kościoła decyduje tradycja zawarta w pismach Ojców, przede wszystkim Augustyna, oraz świadectwo wiary świętych ${ }^{40}$. Zasadniczym celem referowanej tu nauki jest obrona autorytetu papiestwa opartego na sukcesji apostolskiej oraz Tradycji Kościoła.

Zauważyć należy, że w wielu miejscach wykład Antoniego z Napachania odpowiada opublikowanej rok wcześniej nauce o Kościele Stanisława Hozjusza, szczególnie gdy mowa o wiernych jako mistycznym ciele Chrystusa oraz o społeczności świętych. Hozjusz pochylił się nad zagadnieniem instytucji papiestwa w wydaniu swego Chrześcijańskiego wyznania wiary katolickiej z 1557 r., powtarzając argumentację za następstwem Piotrowym oraz apostolską sukcesją biskupów w kolejnych edycjach tego kompendium ${ }^{41}$.

Benedykt Herbest, autor najobszerniejszego, ale też najbardziej komunikatywnego katolickiego katechizmu, jaki w XVI w. otrzymali Polacy ${ }^{42}$, obronę swego Kościoła podejmuje już we wstępie dzieła.

39 Ibidem, k. 10ver.; por. N. Widok, Klemens Rzymski o sukcesji apostolskiej, „Vox Patrum”, 62, 2014, s. 541-550.

40 Antoni z Napachania, op. cit., k. 1rec.-9rec.

41 S. Hozjusz, Chrześcijańskie wyznanie wiary katolickiej albo Wyjaśnienie wyznania ztożonego przez ojców zebranych na synodzie prowincjonalnym, który odbyt się $w$ Piotrkowie roku pańskiego tysięcznego pię́setnego pięćdziesiątego pierwszego, $w$ miesiącu maju [z mogunckiego wyd. roku 1557], tł. J. Wojtkowski, Olsztyn 1999, s. 83-85; por. m.in. idem, Confessio catholicae fidei christiana: vel potius explicatio quaedam confessionis, in synodo Petricoviensi factae M.D.LI., Antverpiae 1561 [1562] (Universidad Complutense de Madrid, Biblioteca de la Facultad de Filosofía, sygn. 18367), k. 51 rec.-59rec. (korzystałem z wersji zdigitalizowanej: googlebooks.pl); por. Universal Short Title Catalogue, ustc.ac.uk/index. $\mathrm{php} / \mathrm{record} / 405017$.

42 B. Herbest, Nauka prawego chrześcijanina, Kraków 1566 (BJ, sygn. Cim. 339, druk o nieregularnej foliacji). O Herbeście zob.: H. E. Wyczawski, Herbest (Herbestus, Neapolitanus) Benedykt, w: SPTK, t. 2, red. H. E. Wyczawski, Warszawa 1982, s. 36-37; S. Rabiej, Herbest, Herbestus Neapolitanus, Benedykt SJ, w: Encyklopedia katolicka, t. 4, red. J. Walkusz, Lublin 1993, szp. 741. 
Powtarza tam znane już argumenty: Kościół rzymski jest Kościołem Tradycji i znaków, które w nim miały miejsce, o jego prawdziwości przekonują święci, którym Bóg dał moc czynienia cudów. Nowe kościoły nie posiadają takich wiarygodnych świadków wiary, a ewangelicy cuda Boże przypisują Belzebubowi. Tymczasem właśnie odejście od Kościoła oznacza odejście od Chrystusa, czyli poddanie się szatanowi. Przywołując te same co Antoni z Napachania przypowieści biblijne, tłumaczy, że w Kościele są też grzesznicy, ale oni nie korzystają z darów Ducha Świętego. Z ich powodu nie należy opuszczać „prawdziwego" Kościoła ${ }^{43}$.

W komentarzu do stosownego artykułu w Credo wyraża pragnienie, aby prości ludzie nauczyli się mówić „święty kościół powszechny”, co oznacza Kościół Chrystusowy, poświęcony Duchem Świętym, który każdy otrzymuje na chrzcie. O takim Kościele nauczali apostołowie, o tym zaś, że ma być powszechny, zdecydował Chrystus, rozsyłając ich do pogan. Za prefigurację tego Kościoła uznaje potomstwo Abrahama i nawiązuje ponownie do biskupa Hippony (do słów: „sparsum est semen sanguinis, surrexit seges ecclesiæ” ${ }^{44}$.

Wszystkie inne wspólnoty chrześcijan określa jako „nowopoczęte” i tak definiuje przyczyny ich odrębności od Kościoła katolickiego: „Przed tym też żaden inny kościół nie był po wszystkim świecie; jedno ten, który Ojca Świętego, papieża słuchał. Głupstwo tedy jest innego szukać kościoła" ${ }^{45}$. Znowu i nie po raz ostatni przywołuje Augustyna: wierzą „heretycy” w to, czego nie widzieli (wniebowstąpienie Pańskie), nie wierzą temu, na co patrzą, a mianowicie, że prawdziwa chwała Boża panuje w Kościele powszechnym. Za Augustynem (Sermones de tempore, 109) pisze, że tak jak „dwa nas rodzice urodzili na śmierć, Adam i Ewa, dwa też nas rodzą na żywot wieczny, Chrystus i Kościól. [- - A kto by zasię nie chciał mieć na ziemi Kościoła Matką, ten nie będzie miał w niebiesiech Pana Boga Ojcem”46. Kościół ze swymi sakramentami i liturgią wyznacza bezpieczną drogę do zbawienia; należy, z jednej strony, do korporacyjnego świata, z drugiej zaś istnieje poza miejscem i czasem jako zbiorowość żywych i zmarłych; nigdy nie błądzi, zawsze daje świadectwo prawdzie, opiera się

43 B. Herbest, op. cit., k. 96rec.

44 Jest to parafraza wypowiedzi Tertuliana; Sermo 22, 4, 4; zob. C. Mohrmann, Saint Jérôme et Saint Augustin sur Tertullien, „Vigiliae Christianae”, 5, 1951, s. 111-112.

45 B. Herbest, op. cit., k. 84ver.

46 Ibidem, k. 98rec.-98ver. 
na powadze Chrystusa, reprezentowanej przez „koncylia apostolskie i biskupie" ${ }^{47}$.

Źródło mądrości wypływa - zgodnie z tradycją biblijnych ksiąg mądrościowych - z bogobojności: „Mędrszy jest jeden chłopek bogobojny nad wszystkie wszystkiego świata filozofy o Pana Boga niedbające" ${ }^{48}$. Autor, wolno sądzić, nawiązuje tym samym do przekonania podzielanego przez przynajmniej niektórych zwolenników starego porządku, a przede wszystkim - przez jego kontestatorów, o wątpliwej czy ograniczonej przydatności rozumu dla poznania prawd objawionych. O ile jednak konsekwencją tego dla ewangelików było poznawanie Pisma „sercem” ${ }^{49}$, Herbest bezpiecznego gruntu dla formacji religijno-moralnej chrześcijanina oraz całego Kościoła upatruje przede wszystkim $\mathrm{w}$ kalendarzu liturgicznym. Ten, spleciony $\mathrm{z}$ rocznym cyklem przyrody, obfitował w praktyki modlitewne usankcjonowane przez zwyczaj i pamięć pokoleń ${ }^{50}$. Herbest określa je jako „przypomnienie dla prostych ludzi" ${ }^{2}$. Szczegółowo argumentuje zasadność takich paraliturgicznych zabiegów jak: święcenie owsa, wina, dzwonów, pól etc., procesje w dni krzyżowe, przed świętem Wniebowstąpienia Pańskiego. Chwali, że dobrzy, prości ludzie zachowują te zwyczaje. Ma świadomość pogańskiej genezy niektórych takich praktyk, ale aprobuje postępowanie Kościoła, który zaadaptował je do własnej pedagogiki.

Według autora Kościół proponuje na każdy dzień praktyki prowadzące do zbawienia; są to nie tylko niedzielna msza czy towarzysząca jej procesja, lecz także codzienne wizyty w kościele, kropienie się wtedy wodą święconą („żegnaj się krzyżem świętym, patrz na ściany, na ołtarze, na obrazy; [- ] słuchaj, co czytają, albo co śpiewają" $)^{52}$. Dodaje, że szatan boi się wody święconej przypominającej o chrzcie. Jej moc płynie z modlitwy i słowa kapłańskiego, a w szczegółowo objaśnianych gestach zawiera się summa wiary

47 Ibidem, k. 98rec.

48 Ibidem, k. 89rec.

49 Zob. szerzej K. Meller, „Noc przeszta, a dzień się przybliżyt”. Studia o polskim piśmiennictwie reformacyjnym XVI wieku, Poznań 2004, s. 174-184.

$50 \mathrm{O}$ genezie i powszechności niektórych takich zwyczajów zob. B. Wojciechowska, Od godów do św. Eucji. Obrzędy doroczne w Polsce późnego średniowiecza, Kielce 2000.

51 B. Herbest, op. cit., k. 102rec.-102ver.

52 Ibidem, k. 112ver. Zalecenia te nie odbiegają więc od skądinąd dobrze znanych pouczeń kierowanych do wiernych, zob. I. Skierska, Obowiazek mszalny $w$ średniowiecznej Polsce, Warszawa 2003, s. 202-205. 
chrześcijańskiej i „pilne rzeczy zbawiennych przypomnienie”53, podobnie jak w znajdujących się w świątyni wizerunkach (np. krzyż na tęczy zwraca uwagę na pośrednictwo Pańskie). Nic więc dziwnego, iż rozmawiający z duchownym mieszczanin podkreśla, że widok Ukrzyżowanego wzrusza go aż do "grzechów zohydzenia”. Duchowny replikuje: „znaków zwierzchnich nam potrzeba i naprostsza babka, co jest znak a co rzecz znaczona, wie barzo dobrze. [- - ] Dziwna rzecz, iż ci nowowiernicy niszczą Boże umęczenia gdziekolwiek ich widzą; alboć nie są chrześcijany?" ${ }^{44}$ Lekceważenie wobec wizualnych przedstawień uznaje za przejaw nowej mody, wyraźnie przeciwstawionej dawnym, dobrym zwyczajom („starzy nie tak czynili”55), wśród których wymienia jeszcze stawianie Bożej Męki na polach, rozstajach dróg, przy szpitalach. Pozytywnie wypowiada się o żebrzących pod kościołami ubogich, swym postępowaniem przypominających o „mizeryji tego świata" ${ }^{6}$ i tym samym pełniących istotną rolę w boskim planie zbawienia. Herbest kreśli więc obraz Kościoła powszechnego silnego wiarą, dziedziczoną z pokolenia na pokolenie. Jak wiadomo, poczesne miejsce zajmowały w niej paraliturgia oraz sakramentalia. Zalecany przez prawodawców, tak we wcześniejszych, jak również w kolejnych wiekach, umiar w korzystaniu z tego oręża w walce o dusze wiernych pozostawał na ogół w sferze deklaracji. Od takich praktyk, nad którymi czuwać mieli parafialni duszpasterze, bliska była bowiem droga do zachowań zabobonnych. Herbest zdaje się być świadom takiego ryzyka i ceny, jaką zapłacić trzeba za spoistość Kościoła, niezagrożoną i pewną, choć niekoniecznie opartą na pogłębionym zrozumieniu prawd wiary.

Kościół powszechny - poprzez liturgię w cyklu rocznym i dziennym, sprawowaną w kościele i w domu, w szpitalu, na polu, na drogach, przez znaki i obrzędy, mszę - uczy o Chrystusie Ukrzyżowanym, przypomina o konieczności przestrzegania Jego woli. Od tej konstatacji Herbest zaczyna odpowiadać na pytanie: „czemuż ci nowi chrześcijanie święte rzeczy ganią, czemu i msze, i godziny wyrzucają

53 B. Herbest, op. cit., k. 113rec.

54 Ibidem, k. [113’ver. nlb.]. Późnośredniowieczna pobożność pasyjna miała za cel nakłonienie do odnowy moralnej poprzez wzbudzenie emocjonalnego przeżycia religijnego. Szerzej na ten temat zob. J. J. Kopeć, Nurt pasyjny w średniowiecznej religijności polskiej, w: Męka Chrystusa wczoraj i dziś, red. H. D. Wojtyska, J. J. Kopeć, Lublin 1981, s. 52-59.

55 B. Herbest, op. cit., k. [113'ver. nlb.].

56 Ibidem, k. 114rec. 
z kościołów?" 57 Obrazy świętych męczenników (głównie z okresu formatywnego Kościoła, aczkolwiek wspomina także o św. Wojciechu), przedstawienia męczennic, „młodziuchnych panienek”, skutecznie wzmacniają w wierze, znajdują potwierdzenie w praktykach Kościoła pierwszych chrześcijan i zaleceniach Ojców ${ }^{58}$.

Obszernie broniąc zwyczajów najczęściej i najmocniej atakowanych przez innowierców ${ }^{59}$, odwołuje się jednak nie tylko do tradycji Kościoła powszechnego i pism teologicznych, lecz również do wydarzeń z historii Polski. Przypomina bowiem o pobożności polskich monarchów, którą stawia innowiercom za wzór, a która przejawiała się m.in. w przeniesieniu zwłok św. Stanisława ze Szczepanowa do katedry wawelskiej ${ }^{60}$.

Porusza także kwestię odpustów i ich zasadności upatruje w zwyczaju pierwszych chrześcijan. Konfrontacja przeszłości z teraźniejszością prowadzi duchownego do krytyki niektórych zachowań; opowiada się za powrotem do publicznej pokuty grzeszników, ale zachowuje dystans wobec kwestii nauczania wiary w domach - nawet wtedy, gdy mieszczanin przypomina mu, że tak przecież czynili Chrystus i apostołowie. Potępia również katechezę w gronie rodziny jako wątpliwej jakości, na co zapewne wpływ wywarło „domowe nabożeństwo" powszechne wśród ewangelików (jego rolę w formowaniu właściwych postaw religijno-moralnych wysoko oceniali reformatorzy). Duchowny nie jest tu jednak konsekwentny, gdyż, chwaląc swego świeckiego interlokutora za dobrą znajomość ewangelicznych wskazań, powtarza jego odpowiedź, że naukę tę czerpał z wyjaśnień ojca, który Ewangelię znał na pamięć, chociaż nie był „literakiem”"61. Zwalcza nadto odziedziczone po poprzednich wiekach i rozpowszechnione wśród współczesnych błogosławienie ślubów szlachty w domach.

Kościół Herbesta to zbiorowość duchownych i świeckich wypełniających codzienne obowiązki religijne i zmierzających na spotkanie z Bogiem. Autor broniąc nauk swej wspólnoty, nie czyni tego

57 Ibidem, k. 116rec.

58 Ibidem, k. [119rec.-119ver. nlb.].

59 O tym m.in. B. Wojciechowska, Krytyka religijności katolickiej w pismach Mikotaja Reja, w: Mikotaj Rej z Nagtowic. W pięćsetna rocznice urodzin, red. W. Kowalski, Kielce 2005, s. 323-339.

60 Od 1254 r. spoczywały w ozdobnej trumnie, w centralnym miejscu świątyni, zob. M. Rożek, Katedra wawelska w XVII wieku, Kraków 1980 (Biblioteka Krakowska, nr 121), s. 68.

61 B. Herbest, op. cit., k. [108'rec. nlb.]. 
w sposób bezkrytyczny - zwłaszcza względem postępowania braci w kapłaństwie. Konkluduje jednak: „wszakże nie co kapłan czyni, ale czego uczy więcej masz przestrzegać", w innym zaś miejscu dodaje: „zaiste czasem lepiej by milczeć, niźli źle kazać”62.

Mniej rozwinięty, choć oparty na takich samych przesłankach wykład o „prawdziwym” Kościele znajdujemy w katechizmie Marcina Białobrzeskiego, biskupa sufragana diecezji krakowskiej ${ }^{63}$. Ton tego teologa i polemisty jest bardziej agresywny. Znów czytamy o Kościele zbudowanym przez Piotra i Pawła, którego głową jest Chrystus, o sukcesji apostolskiej papieży oraz o męczennikach dających świadectwo wiary Kościoła. Biskup dodaje jednak, że choć w Kościele rzymskim są grzechy i grzeszni, „błędów kacerskich i kacerzów” w nim nie ma. Kościół jest jeden i tylko tam, gdzie owce słuchają głosu swego pasterza (J 10,1-16) i nawet jeśli w tej owczarni nie wszyscy zawsze żyją Ewangelią, to i tak „nie mamy opuszczać Boga dla diabła”64.

Zdrowe słowo Boże jest słowem pokoju, fałszywe mnoży niezgodę i wojny. Jako przykład podaje powstanie chłopskie w Niemczech oraz konflikty między miastami szwajcarskimi ${ }^{65}$. Przed konsekwencjami sporów wśród chrześcijan, jak te w Rzeszy i Szwajcarii, ostrzegał już w epoce patrystycznej św. Bazyli, wspominając Kościół zwyciężony przez arian. Białobrzeski pokazuje też, że zerwanie z Kościołem dało początek wojnie w Inflantach, w którą zaangażowało się Królestwo Polskie. Na dowód tego, że Kościół prawdziwy, powszechny zawsze walczył z odszczepieńcami, przywołuje słowa Augustyna przeciw donatystom. Konwersji na nowe wyznania nie ujmuje jako straty, gdyż niegdyś, kiedy Żydzi odeszli od prawdziwej wiary, Bóg w ich miejsce powołał pogan. Wspomina egzekucje zwolenników Kościoła

62 Ibidem, k. 82ver.-140rec., tu k. 135rec., 136ver.

63 M. Białobrzeski, Katechizm albo wizerunk prawey wiary chrześciańskiej wedle nauki Pana Jezusa Chrystusa, Apostotów iego y Kościota iego świętego przeciwko wszytkim obtędliowościam tych czasów barzo pożyteczny, Kraków 1566 [lub 1567] (BJ, sygn. Cim. 4452; zob. Katalog poloników XVI wieku Biblioteki Jagiellońskiej, t. 1: $A-E$, red. M. Malicki, E. Zwinogrodzka, oprac. M. Gołuszka et al., Warszawa-Kraków 1992, s. 85). O autorze zob.: H. E. Wyczawski, Biatobrzeski Marcin, w: SPTK, t. 1, s. 131-132; M. Brzozowski, Biatobrzeski Marcin OCist, w: Encyklopedia katolicka, t. 2, red. F. Gryglewicz et al., Lublin 1995, szp. 365-366.

64 M. Białobrzeski, op. cit., k. nlb. przedmowy.

65 Był to argument powszechnie przytaczany przez katolików. Szerzej na ten temat zob. J. Tazbir, Szlachta i teologowie. Studia z dziejów polskiej kontrreformacji, Warszawa 1987, s. 71-94. 
rzymskiego w Niemczech, Anglii i Francji. Nawiązanie do martyrologii współczesnego Kościoła, choć wskazywane w polemikach wyznaniowych $^{66}$, nie występuje w interesującym nas kontekście w pozostałych, omawianych tu, katechizmach. W odróżnieniu od autorów innych katolickich druków tego typu, Białobrzeski, wskazując wrogów Kościoła, nie ogranicza się do wiodących europejskich herezjarchów, ale wymienia też Schwenckfelda, Stankara i innych lokalnych kontestatorów „starej wiary”.

Podobnie jak Herbest tłumaczy, że tradycja apostolska to zarówno księgi Nowego Testamentu, jak też ustne dziedzictwo przekazywane z pokolenia na pokolenie. Przyczyn licznych rozterek targających Kościołem upatruje w „dopuszczeniu” Bożym interpretowanym jako kara za grzechy oraz opaczne odsłanianie najgłębszych tajemnic wiary („dwornieśmy chcieli skryte tajemnice wiary naszej wiedzieć, a wszystkim je oznajmić”) ${ }^{67}$. Ratunek dla Kościoła „prawdziwej wiary", na straży której stoi papież z biskupami, widzi w koncyliach - to bowiem "trucizna wszystkim kacerzom" ${ }^{68}$; chwali więc dzieło soboru trydenckiego. Obok typowej nowotestamentowej argumentacji, obficie omawia dzieje Izraela, aby pokazać, do czego prowadzi brak respektu dla woli Boga. Narrację wzmacniają inwektywy, np. „wieprze, które winnicę Pańską targają i psują" ${ }^{99}$ (nawiązanie do Iz 5, 1-7 oraz Mt 20, 1-16; 21, 33-46; winnica symbolizuje łaskę, którą Bóg obdarowuje swój Kościół). Taka ekspresja wypowiedzi, aczkolwiek odstaje od tonu autorów innych, analizowanych w tym artykule, nauk katechizmowych, to mieści się jednak w polemicznym dyskursie tamtych czasów ${ }^{70}$.

Analogiczne treści znajdujemy też w ostatnim omówionym w niniejszym studium druku katolickim, pióra Hieronima Powodowskiego, jednego z najwybitniejszych polskich teologów i kaznodziejów tamtych czasów ${ }^{71}$. Jego wypowiedź sprowadza się do podkreślenia,

66 O ważnym, martyrologicznym kontekście ówczesnej dyskusji wyznaniowej zob. M. Hanusiewicz-Lavallee, Okrucieństwo kacyrskie przeciw katolikom w Anglijej, czyli polski gtos w sporze o męczeństwo, OiRwP, 56, 2012, s. 37-60.

67 M. Białobrzeski, op. cit., k. 132ver.

68 Ibidem, k. 137rec.

69 Ibidem, k. 116rec.-140rec.

$70 \mathrm{O}$ tym m.in. S. Radoń, $Z$ dziejów polemiki antyariańskiej w Polsce XVI-XVII wieku, Kraków 1993, s. 91-118.

71 H. Powodowski, Catechizm Kościota Powszechnego, nauki do zbawienia potrzebnieysze, z dowodow Pisma świętego snadna, a doktadna króthkościa zamykający [- -] książki bardzo pożyteczne [- -], Poznań 1577 (BJ, sygn. Cim. 541). 
że Kościół powszechny zachowuje jedność wiary i nauki. Inne wyznania są „pokątne, rozerwane, nowe i odmienne; kościołem prawym Krystusowym być nie mogą" ${ }^{2}$. Świętość Kościoła wyraża się w jego sakramentalnej posłudze, z tego więc powodu tylko w Kościele można doświadczyć łaski Bożej nieodzownej do zbawienia. Kościół - społeczność żywych i umarłych wspomagających się modlitwą - rozumie jako „świętych obcowanie”73.

\section{Źródła ewangelickie}

Do wczesnych lat sześćdziesiątych XVI w. ruch reformacyjny w Królestwie Polskim nie posiadał wykrystalizowanego oblicza ideowego. U początków tego ruchu, naturalną koleją rzeczy, kontestujący tradycyjny porządek kościelny inspirowali się naukami Lutra i Melanchtona. Tak było w Małopolsce, w Wielkopolsce, gdzie w latach pięćdziesiątych bracia czescy utworzyli osobny kościół, oraz w Wielkim Księstwie Litewskim, gdzie od 1556 r. rozwijał się nadto antytrynitaryzm. Do około lat 1553-1557 założenia teologiczne Kalwina znano tylko pobieżnie. Jako ich autora wskazywano niekiedy Zwingliego, którego naukę przyswojono w bliżej nierozpoznanym stopniu. W okresie formatywnym polskiego ruchu reformacyjnego sięgano więc do wielu źródeł, częściej niż Genewa były to Bazylea i Zurych. Ruch ten miał, ogólnie rzecz ujmując, antyrzymski charakter, postulowano odrzucenie z nauki Kościoła katolickiego wszystkiego, co stoi w sprzeczności z Pismem. Nauka Jana Kalwina przyjęta została jako wiodąca około 1560 r., wraz z umocnieniem się ewangelickiej struktury organizacyjnej ${ }^{74}$.

O autorze zob.: E. Ozorowski, Powodowski (Povodovius, z Powodowa) Hieronim, w: SPTK, t. 3, s. 430-432; R. Skrzyniarz, Powodowski Hieronim, w: Encyklopedia katolicka, t. 16, red. S. Wilk et al., Lublin 2012, szp. 141-142.

72 H. Powodowski, op. cit., s. 25.

73 Ibidem, s. 25-26.

74 Zob. przede wszystkim: J. T. Maciuszko, Poglady religijne Mikotaja Reja, w: Mikotaj Rej z Nagtowic, s. 302-307; M. Kosman, Protestanci i kontrreformacja. $Z$ dziejów tolerancji w Rzeczypospolitej XVI-XVIII wieku, Wrocław 1978, s. 20-26; J. Dworzaczkowa, $Z$ dziejów Braci Czeskich w Polsce, Poznań 2003, s. 18-21; K. Bem, "From Many Different Sources". The Formation of the Polish and Lithuanian Reformed Liturgy, w: Liturgy in Migration. From the Upper Room to Cyberspace, ed. by T. Berger, Collegeville 2012, s. 101-130; J. Urban, Reformacja $w$ życiu wsi matopolskiej, w: Et haec facienda et illa non omittenda. Profesor Wactaw Urban w swych dzietach wybranych, red. A. Kądziela et al., Warszawa 2012 (Opera Necessaria), s. 25-39. 
Wydany po raz pierwszy w 1543 r. w Krakowie anonimowy druk Catechismus to jest nauka barzo pożyteczna kazdemu wiernemu krześcijaninowi jako się ma $w$ zakonie Bożym a $w$ wierze i $w$ dobrych uczynkach sprawować to chronologicznie pierwszy znany polski podręcznik wychowania religijnego pisany $\mathrm{w}$ duchu reformacyjnym. Podstawą dzieła był ogłoszony w 1535 r. w Wittenberdze Catechismus minor puerorum pióra współpracownika Lutra, Urbana Rhegiusa ${ }^{75}$. Badacze na ogół zgadzają się co do istotnego udziału Mikołaja Reja z Nagłowic w powstaniu tej polskiej adaptacji. Jak wykazał Janusz T. Maciuszko, katechizm propaguje poglądy reformacyjne w takim stopniu, $\mathrm{w}$ jakim było to możliwe pod Wawelem do schyłku lat czterdziestych XVI stulecia, to jest do czasu wstąpienia na tron w 1548 r. Zygmunta Augu$\mathrm{sta}^{76}$. W przeciwieństwie do swego ojca, ostatni z polskich Jagiellonów „pozwalał żyć, jak się każdemu podoba”77.

Swoją postawę eklezjalną Rej deklaruje już na wstępie stosownych rozważań: „Wierzę, iż jest jedno zebranie Kościoła świętego krześcijańskiego. Nie iżby miał wierzyć w zebranie Kościoła krześciińskiego, ale iż ma być wedle Christusa i jest zebranie Kościoła krześciańskiego" 78 . Dalej tłumaczy, że należy wierzyć tylko Bogu, „abowiem zebranie Kościoła świętego właśnie samemu Panu należy"79. Definicja Kościoła nie może więc być przedmiotem dyskusji. Z woli Najwyższego jest jeden Kościół Chrystusowy, nad którym opiekę sprawuje Bóg, jak gospodarz nad domem lub starosta nad miastem.

W nawiązaniu do św. Augustyna (bez szczególnego wskazania) Rej mówi, że zarówno pielgrzymujący na tym świecie, dusze poświęcone

75 Analizę teologiczną krakowskiego druku przedstawia R. M. Leszczyński, Nauka ewangelicko-reformowana w polskojęzycznych katechizmach z XVI wieku, w: Ewangelicyzm reformowany $w$ pierwszej Rzeczypospolitej. Dialog z Europa i wybory aksjologiczne w świetle literatury i piśmiennictwa XVI-XVII wieku, red. D. Chemperek, Warszawa 2015 (Kultura Pierwszej Rzeczypospolitej w Dialogu z Europą. Hermeneutyka Wartości, t. 9), s. 69-74.

76 J. T. Maciuszko, Mikotaj Rej. Zapomniany teolog ewangelicki z XVI w., Warszawa, 2002, s. 83-115. Taką datę pierwodruku oraz autorstwo przyjęli autorzy Universal Short Title Catalogue, ustc.ac.uk/index.php/record/244559.

77 Zob. A. Januszek-Sieradzka, W co wierzyt król Zygmunt August?, w: Rycerze, wędrowcy, kacerze. Studia z historii średniowiecznej i wczesnonowożytnej Europy środkowej, red. B. Wojciechowska, W. Kowalski, Kielce 2013, s. 281.

78 J. T. Maciuszko zauważa, że „wywód Rejowy gubi całą dobitność i lapidarność [- ] wypowiedzi teologa niemieckiego [- ] Non enim credimus in Ecclesiam, cum ecclesia sit creatura, sed credimus ecclesiam esse”, idem, Mikotaj Rej, s. 104.

79 Catechismus, k. 44ver. 
Bogu w niebie i aniołowie stanowią jeden Kościół. Chrześcijan w Kościele ponad wszelkimi podziałami łączy wiara, bo wszyscy, choć służą Bogu w różnych miejscach i zgromadzeniach, tworzą jeden Kościół jednej wiary, opartej na Piśmie i sakramentach. Jest to więc „wszytka społeczność przebranych boskich przez wiarę, aczbykolwiek byli od siebie daleko rozdzieleni różnością" ${ }^{\circ}$. Do Kościoła prowadzi chrzest poprzez działanie Ducha Świętego. Na pytanie żaczka: „A gdzież tedy tego Kościoła świętego szukać mamy?”, mistrz odpowiada, zgodnie z Lutrem: „gdziekolwiek jest słowo Pańskie wiernie przepowiedane a chowane i inne świątości jego, tam jest prawy Kościół" ${ }^{\prime}$. Sakramenty, które wymienia (chrzest, małżeństwo, pamiątka wieczerzy Pańskiej „i innych niemało”), zbieżne są z katalogiem sakramentów sprawowanych w Kościele katolickim, stąd Janusz T. Maciuszko pisze o „(krypto)reformacyjnym” podejściu Reja, który nie chce otwarcie kontestować rzymskiej nauki ${ }^{82}$.

Tłumacz, co podkreśla przywoływany badacz, rezygnuje z określenia Rhegiusa „Kościół prawdziwy” na rzecz przymiotnika „jednostajny” (jednakowy, niezmienny). Rezygnację tę interpretować wypada, twierdzi Maciuszko, wiarą Reja, że dojdzie do zjednoczenia chrześcijan, zapewne w duchu ewangelickim, lub określenie „prawdziwy" nie zostało wykorzystane z przyczyn cenzuralnych ${ }^{83}$. Wskazać można jednak jeszcze jedną możliwość interpretacyjną, bardzo bliską omówionej wyżej wstępnej eklezjalnej deklaracji. Sądzę, że Rej chciał jeszcze mocniej podkreślić, zapewne pod wpływem Melanchtona (i być może Bucera) ${ }^{84}$, że taka niezmienna i jednomyślna wspólnota chrześcijan złączona Duchem Świętym jest już faktem, choć nie doszło jeszcze do pełnego objawienia Królestwa Chrystusowego,

80 Ibidem, k. 45rec. Jak wspomniano, tak definiowała wspólnotę Kościoła większość ówczesnych teologów ewangelickich, włączając Łaskiego; por. H. Kowalska-Kossobudzka, Jana Easkiego pojęcie, s. 100.

81 Catechismus, k. 46rec.

82 Ibidem, k. 46rec.; por.: J. T. Maciuszko, Mikotaj Rej, s. 105; R. M. Leszczyński, op. cit., s. 70-71.

83 J. T. Maciuszko, Mikotaj Rej, s. 104.

84 Por.: R. Keen, Political Authority and Ecclesiology in Melanchthon's De ecclesiae autoritate, „Church History”, 65, 1996, s. 1-14; W. van't Spijker, Bucer's Doctrinal Legacy as Formulated in his Last Three Wills and Testaments, "Reformation and Renaissance Review”, 3, 2001, s. 162-164; P. Matheson, Martin Bucer and the Old Church, w: Martin Bucer. Reforming Church and Community, ed. by D. F. Wright, Cambridge-New York, 1994, s. 6, 13-15; zob. też J. T. Maciuszko, Poglądy religijne, s. 306-307. 
jak czytamy w Obronie wyznania augsburskiego. Określenie to, umieszczone w kontekście wskazanym przez Melanchtona, miałoby wymowę antykatolicką. Jak dowiódł Janusz T. Maciuszko, Rej rezygnuje z jednoznacznych deklaracji Rhegiusa, który przytacza Konfesję augsburską i potępia kult świętych. Niemniej jednak Rejowa definicja Kościoła, miejscami niejednoznaczna, ma ogólnie reformacyjną wymowę.

Jest to czytelne w dalszych wywodach, gdy mistrz stwierdza, że, mimo zakusów Kościoła katolickiego, „zebrania krześcijańskiego płotem ogrodzić nie może" ${ }^{25}$. Przystaje na sugestię, że w „prawdziwym” Kościele są też tacy, którzy nie przestrzegają nauk Chrystusa. $\mathrm{Ci}$ jednak to kąkol i zostanie on wyrwany przez Dobrego Gospodarza (Mt 13, 3), chociaż, przypomina jednocześnie, że Bóg nie opuści „świętych a przebranych Bożych”. Nie dostąpią natomiast zbawienia „odszczepieńcy”, to jest ci, którzy nie dochowują wierności prawu Bożemu, Ewangelii oraz nie przystępują do sakramentów, a więc nie dotyczy to ex definitione luteranów ${ }^{86}$.

Zgodzić należy się z Januszem T. Maciuszko, że Rej formułował myśli tak, aby dać szansę dystrybucji swego dzieła. Tym bardziej należy podziwiać jego kunszt w adaptacji pierwowzoru. Przypomnieć warto, że gdy około roku 1548-1549 katechizm tłoczono w typografii Heleny Unglerowej, jego autor/adaptator był już obłożony ekskomuniką za uchylanie się od należności na rzecz krakowskiej kolegiaty św. Anny ${ }^{87}$.

Współczesny Rejowi Jan Seklucjan, zasłużony dla promocji luteranizmu w Królestwie Polskim ${ }^{88}$, sformułował swe poglądy eklezjalne w Wyznaniu wiary (1544), a następnie w katechizmie (opublikowanym w latach 1547, 1549 [faktycznie 1548] i 1568) ${ }^{89}$. Dzieła

85 Catechismus, k. 46ver.

86 Ibidem, k. 47ver.-48ver. unikatowego egzemplarza w BJ (sygn. Cim. 219), reedycji przypuszczalnie z lat 1548-1549, bez karty tytułowej; J. T. Maciuszko, Mikotaj Rej, s. 86; Universal Short Title Catalogue, ustc.ac.uk/index.php/ record/241486. Druk ten konfrontowałem z pierwszym wydaniem ogłoszonym przez F. Pułaskiego, Catechismus to jest nauka barzo pożyteczna każdemu wiernemu krześcijaninowi, jako się ma $w$ zakonie Bożym a wierze $i w$ dobrych uczynkach sprawować: 1543 r., Kraków 1910, s. 62-66.

87 W. Urban, Z. Kłosińska, Klątwy przeciwko Rejowi, w: Et haec facienda et illa non omittenda, s. 559-566.

88 J. Seklucjan, Wybór pism, oprac. S. Rospond, Olsztyn 1979, s. v-xi.

89 Idem, Wyznanie wiary chrześcijańskiej, oprac. H. Kowalska, S. Rospond, Warszawa 1972 (Biblioteka Pisarzy Reformacyjnych, nr 10); idem, Catechismus to 
służyły dydaktyce. Choć Wyznanie wiary chrześcijańskiej propaguje przede wszystkim idee luteranizmu, wydawcy tego źródła są zdania, że definicja Kościoła lepiej odpowiada „duchowi wyznaniowemu kościołów reformowanych niż zboru luterańskiego”. Jak zaznaczają, według Lutra, Chrystus zbudował Kościół na wierze Piotrowej, Seklucjan sądzi zaś, że Kościól, którego głową jest Chrystus (1 Kor 6, 19; Ef 5, 23; Kol 1, 18), oparty został "na mocnej opoce Pisma Świętego" ${ }^{\text {, }}$, dlatego chrześcijanie nie mają prawa nic tu zmieniać. Wspiera się pismami Augustyna przeciw manichejczykom. Stanowisko Seklucjana pozostaje więc w głównym nurcie na ogół, jak wskazano, bardzo bliskich sobie ówczesnych poglądów reformacyjnych i doszukiwanie się bezpośredniej inspiracji wydaje się poznawczo mało płodne.

Reformator dopuszcza, że prawdziwych chrześcijan spotkać można nawet w Rzymie. Jeśli biskup rzymski uczy z „katedry Mojżeszowej a z Ewangelijej świętej”, to trzeba go słuchać „jako samego Boga”. Tak też traktuje Lutra i innych kaznodziejów, bowiem „nie dla persony złej, ale dla słowa Bożego prawdziwego mam naukę dobrą, prawdziwą przyjmować" 91 .

W katechizmie Seklucjan wychodzi od pojęcia Kościoła jako ogólnej zbiorowości wszystkich, którzy zawierzyli Słowu, przystępują do sakramentów, ale też potwierdzają swą wiarę dobrymi uczynkami. Wierzący prawdziwie są „świętym, żywym Kościołem Chrystusowym, [- - bractwem i kapłaństwem świętym i ciałem Chrystusowym"92, co jest echem poglądu o powszechnym kapłaństwie wszystkich ochrzczonych. Kościół prawdziwy, zbudowany na Słowie Bożym, radzi poznawać „Z owoców i uczynków”93 (Mt 7, 16), czemu dali początek pierwsi rodzice, gdy uwierzyli w zapowiedź Boga o zwycięstwie Chrystusa Zbawiciela i głowy Kościoła - nad szatanem. Fałszywy Kościół kościół papieski - zastąpił Słowo wymysłami ludzkimi, zrezygnował z komunii pod dwiema postaciami. Seklucjan gani pasterzy, którzy „zapamiętawszy urzędu swego, sami się pasą i zowią się Kościołem, pożerając majętności ubogiego Kościoła żywego, a Kościół żywy

iest nauka naprzednieisza y potrzebnieisza ku zbawyenyu o wierze krzescianskiej, Królewiec 1547 (BCz, sygn. Cim. 1880), k. nlb.; idem, Catechismus to iest krotka a prosta (starey wiary chrzesciańskiey) nauka powtore wydana, Królewiec 1549 (BN, sygn. SD XVI.O.6247 adl.), k. nlb.

90 Idem, Wyznanie wiary, s. ix-X.

91 Ibidem, s. 11-12.

92 J. Seklucjan, Catechismus, k. nlb.

93 Ibidem, k. nlb. 
nędzę cierpi pod płotem leżąc”, tacy są "gorsi niźli wilcy drapieżni”. Wzywa następnie, aby, zamiast dbać o wystawne zdobienia świątyni, wspomagać potrzebujących („ty przyodziej Pana Chrystusa w ubogich Jego" ${ }^{44}$ ). Mamy tu więc do czynienia z wykładem luterańskiej eklezjologii mieszczącym się w szerszym nurcie stosownej nauki wspólczesnych Seklucjanowi reformatorów. Słychać też tu echa wielowiekowej krytyki Kościoła jako korporacji osadzonej w realiach społecznych swych czasów, głoszonej z szeregów zwolenników ewangelicznego ideału wspólnoty ubogich ${ }^{95}$.

Przypomnieć należy tu wkład w ewangelizację w duchu luterańskim, również związanego z Królewcem, Jana Sandeckiego-Maleckiego. Seklucjan i Malecki, mając wspólny cel, protektora i typografa, jako autorzy katechizmów pozostawali w twórczym konflikcie. Przedstawiając Credo, zarówno w małym katechizmie ogłoszonym w 1545, jak też w wydaniu z 1547 r., Seklucjan powtarza tradycyjną katolicką formułę „święty kościół chrześcijański”. Malecki zmienia ją na „święte zebranie chrześcijańskie”, „świętych obcowanie” zaś na „świętych pospólstwo”, co zdaje się dobitniej oddawać intencje Lutra (kościół zgromadzeniem wiernych, nie zaś instytucja $)^{96}$. Na dworze w Królewcu zdania na ten temat musiały być jednak podzielone. Eustachy Trepka, polski tłumacz popularnego katechizmu wybitnego reformatora i ucznia Lutra, Johannesa Brenza, służący swym talentem księciu Albrechtowi, wspomina bowiem „świętą cerkiew chrześcijańską, wobec pospolitą, świętych pobożnych społeczne a jednostajne obcowanie" 97 . Dzieło reprezentuje luterańską ortodoksję, translator wyjaśnia zaś czytelnikowi niektóre zawiłości, świadczące o trudnościach, z jakimi musiał zmagać się twórca przekładu ${ }^{98}$.

94 Ibidem, k. nlb.

95 Por. S. Świeżawski, op. cit., s. 46-47.

96 Druki mazurskie XVI w., wyd. S. Rospond, Olsztyn 1948, s. 22, 38; A. Lenartowicz-Zagrodna, Defensio verae translationis corporis Catechismi in linguam Polonicam, adversus calumnias Joannis Secluciani Jana Maleckiego - przektad wraz z komentarzem, „Poznańskie Studia Polonistyczne. Seria Językoznawcza”, 38, 2011, s. 130-133.

97 Catechismus to iest zupetna nauka chrześciańska przez Jana Brenciusza z pisma prorockiego i apostolskiego zniesiona, ktory możesz dobrze mata Biblia nazwać, Królewiec 1556, k. 122ver.-137rec.; destrukt, bez karty tytułowej (BO, sygn. XVI.Qu. 3191). O druku tym szerzej zob.: A. Korzo, W sprawie, s. 184-186; eadem, Przyczynek, s. 12-14.

98 O tłumaczu i jego warsztacie szerzej zob. K. Kolbuszewski, Postyllografia polska XVI i XVII w., Kraków 1921, s. 44-57. 
Wiarę w jeden Kościół Chrystusowy, „zebranie wiernych i świętych obcowanie”, jedno ciało złączone Duchem Świętym i rządzone słowem Bożym, wyraził też autor Katechizmu mniejszego opublikowanego w Brześciu pod auspicjami Mikołaja Radziwiłła, zapewne na przełomie lat 1553 i 1554 . Kościół ten jest wspólnotą mającą „sakramentu prawdziwe używanie”, dostrzegającą doniosłość zbawczej śmierci Chrystusa, żyjącą jednym duchem, w jednej nauce, wierze, nadziei i miłości. Człowiek dostępuje łaski zbawienia w Chrystusie, który odkupił jego grzechy Krzyżową Ofiarą i w tym kontekście autor wskazuje na znaczenie i wagę sakramentów dla Kościoła. Jest to więc stanowisko ogólnoreformacyjne. Dalej następuje krótki wykład doktryny usprawiedliwienia przez wiarę o raczej luterańskim pierwowzorze $^{99}$. Zagadnienia eklezjologiczne nie doczekały się natomiast systematycznego omówienia w Katechizmie większym, dopełniającym Katechizm mniejszy.

Nieodległe od powyższego stanowisko zajął autor anonimowego katechizmu, który około 1563 r. opuścił królewiecką typografię Jana Daubmanna. Kościół „od Krystusa zebrany z łaski” to, jak się zdaje, echo nauki Kalwina o Kościele jako Królestwie Chrystusa, w którym dyscyplina jest odpowiedzią człowieka na Bożą łaskę ${ }^{100}$.

Kancjonał ogłoszony w Nieświeżu w 1563 r. zawiera dwa katechizmy, z których Wtory katechism szerszy dla więtszych i ćwiczeńszych dziatek jest dziś unikatem i adaptacją jednego z druków bazylejskich ${ }^{101}$. Oryginał wyszedł w latach 1525-1530 spod pióra Jana Oekolampada, wybitnego humanisty. Około 1544 r. katechizm Oekolampada został gruntownie przerobiony i rozbudowany przez Oswalda Myconiusa, niegdyś współpracownika Ulricha Zwingliego w Zurychu. Według Myconiusa prawdziwy Kościół kieruje się Słowem Bożym i korzysta z sakramentów ustanowionych przez Chrystusa. Pomniejszając znaczenie obrzędów i przywołując Augustyna, twierdzi Myconius,

99 Katechizm brzeski, wyd. F. Pułaski, Warszawa 1908 (Collectanea Biblioteki Ordynacji hr. Krasińskich, nr 1), s. 10-11. W innych miejscach tego katechizmu czytelnik zaznajamiany jest przede wszystkim z sakramentologią luterańską, zob. R. M. Leszczyński, op. cit., s. 75-76; por. P. D. L. Avis, Luther's Theology, s. 105; V.-M. Kärkkäinen, An Introduction to Ecclesiology. Ecumenical, Historical and Global Perspectives, Downers Grove (Ill.) 2002, s. 41-49.

100 [Kancjonat], Biblioteka Śląska, Muzeum w Cieszynie, k. D v rec. i następne nieoznaczone. Zob. Y. Kim, The Identity and the Life of the Church. John Calvin's Ecclesiology in the Perspective of his Anthropology, Eugene 2014, s. 156-188.

101 Por. M. Korzo, Przyczynek, s. 7-25. 
że wewnętrznym znakiem przynależności do Kościoła jest bojaźń Boża, co mogło być inspirowane nauką Bucera. Z porównania wykładu Myconiusa z jego polską adaptacją wynika, że jej autor wiernie przekazał eklezjalne stanowisko bazylejskiego pastora ${ }^{102}$. W pierwszej, katechizmowej części kancjonału poprzestano natomiast na zacytowaniu stosownego artykułu Credo.

Obszerny wykład eklezjologii ewangelicko-reformowanej przedstawił w swym katechizmie wspomniany już Paweł Gilowski. Wyodrębnić w nim można dwa przeplatające się nurty: przedstawienie Kościoła widzialnego i niewidzialnego, a nadto - ponadprzeciętnie rozbudowaną - refutację nauki katolickiej ${ }^{103}$. Jeden Kościół to zbór w niebiosach „zgromadzony ku chwale wiecznej”, drugi zaś jest tu na ziemi „bojujący jeszcze”104. Zgodnie z Konfesją sandomierską przypomina też, że z woli Boga Kościół nie może być „więziony” w jednym miejscu ani też łączony z jedną osobą ${ }^{105}$ :

Przetoż nie zowie się Kościół papieski, albo witemberski, auszpurski, genewski, tygurski, konstantynopolski, ale Krystusow, krześciański, nie luterski, zwingliuszow, kalwiński, ale krześciański ${ }^{106}$.

Kościół ten żywi się Słowem Bożym, sakramentami chrztu i wieczerzy Pańskiej, i są to „pewne a niewątpliwe znaki” prawdziwego Kościoła. Jest to stanowisko ogólnoreformacyjne i w tym duchu wypowiadał się też Jan Kalwin, dla którego podstawowym zadaniem Kościoła było głoszenie nauki Chrystusa, aspekt doktrynalny miał zaś wobec tego znaczenie drugorzędne ${ }^{107}$. Do nauczania tego reformatora Gilowski nawiązuje bezpośrednio, podkreślając, że Kościół

102 Ibidem, s. 15. O bojaźni Bożej w nauczaniu Bucera zob. B. Lugioyo, Martin Bucer's Doctrine of Justification. Reformation Theology and Early Modern Irenicism, Oxford-New York 2010 (Oxford Studies in Historical Theology), s. 233, passim.

103 P. Gilowski, op. cit., k. 252rec.-264rec. Bardzo negatywne nastawienie autora do Tradycji w jej katolickim ujęciu zauważyła już A. Kawecka-Gryczowa, por. eadem, Spory o „szczyra prawde”, OiRwP, 23, 1978, s. 228.

104 P. Gilowski, op. cit., k. 253ver.

105 Konfesja sandomierska. Transkrypcja i komentarz jezykowy, oprac. K. Długosz-Kurczabowa, Warszawa 1995, s. 132-135.

106 P. Gilowski, op. cit., k. 255rec.

107 Por. P. J. Naudé, Why is a Multiplicity of Confessions Particular to the Reformed Tradition?, „Acta Theologica”, 20, 2014, s. 39-41; zob. też: H. Kowalska, 'Przejrzani i wybrani', passim; S. Piwko, Jan Kalwin. Życie i dzieto, Warszawa 1995 , s. $120-153$. 
święty Boży to wspólnota wybranych, złączonych Duchem Świętym. Naukę o wybranych wyprowadza z Nowego Testamentu (J 17; Mt 20; Tes 3), toteż „nie wszytek świat, ale ze wszystkiego świata wybrani ludzie są Kościołem świętym, którzy jednę wiarę, jednego ducha mają i pewne swoje poznaczenie" ${ }^{108}$. Kościół od zawsze łączył w sobie dobrych i złych, ale dobre nasienie od kąkolu odróżni Bóg „w ostateczne żniwo”. Świętym człowiek staje się nie poprzez swe uczynki, ale dzięki obmyciu krwią Chrystusa. Obowiązkiem chrześcijanina jest zaświadczać o świętości Kościoła „życiem pobożnym [- - ], boć wiara bez uczynków martwa jest"109. Mamy tu więc podstawowe elementy eklezjologii zborów reformowanych.

Idąc z głównym nurtem reformacji, Gilowski głosi, że polecenie dane Piotrowi „paś baranki moje, [- - ] paś owce moje” (J 21, 15-19) interpretować należy jedynie jako nakaz głoszenia Dobrej Nowiny i za nadużycie uważa wyciąganie domysłów o jakiejkolwiek zwierzchności. Nadto, wbrew katolickiej interpretacji słów Jezusa (Mt 16, 18), intencją Syna Bożego było zbudowanie Kościoła na silnej wierze Piotrowej, lecz nie na Piotrze - człowieku. Interpretację tę przypisuje też Bedzie i konkluduje, że budowanie „na ludziach” prowadzi do poróżnienia chrześcijan, o czym czytamy w Listach Pawła Apostoła. Jednak mimo tak klarownie przedstawionego fundamentu Kościoła żywej wiary, wizja Gilowskiego nie jest jednoznacznie optymistyczna, ponieważ Kościół powszechny słuszniej należałoby wiązać z Jerozolimą, gdyż „tam była katedra naszego biskupa Jezusa Chrystusa”. Jerozolimę opanowali jednak mahometanie, stąd „takżeć i w Rzymie pierwej pogaństwo było, potym krześciaństwo, teraz bluźnirstwo i bałwochwalstwo, co potym będzie - bać się potrzeba" ${ }^{110}$.

Gilowski pozostaje w łączności z nauką Lutra i Kalwina także wtedy, gdy, tłumacząc świętość Kościoła, gani poszukiwanie wspólnoty gromadzącej tylko bezgrzesznych. Wspomina tu tych wszystkich, którzy porzuciwszy dotychczasowych współwyznawców, zgromadzili się w Rakowie, aby żyć, w swym mniemaniu, pobożnie, na modlitwie, z dala od gorszącego świata, temu światu przeciwstawiać „świątobliwość"111. Zrozumieli jednak wkrótce swój błąd. Tak samo czynili też

108 P. Gilowski, op. cit., k. 254rec.

109 Ibidem, k. 259rec.-260rec.

110 Ibidem, k. 254ver.-255rec.

111 Tu ocena Gilowskiego ma poparcie współczesnej historiografii, zob.: S. Tworek, Raków w okresie "nieustającego synodu” (1569-1572), w: Wokót dziejów i tradycji arianizmu, red. L. Szczucki, Warszawa 1971, s. 67-75; E. Campi, op. cit., 
pustelnicy i zakonnicy, których jednak poza wyglądem zewnętrznym nic od zwykłych ludzi nie odróżnia. Jednocześnie jednak chwali decyzję odłączenia się od fałszywej nauki Rzymu, co argumentuje nakazem Chrystusa: strzeżcie się fałszywych proroków (Mt 7, 15).

Interesujące nas zagadnienia bardzo zwięźle przedstawione zostały też w katechizmie zredagowanym przed $1581 \mathrm{r}$. przez seniora zborów litewskich Stanisława Sudrowiusza ${ }^{112}$. Modlitwy zatytułowane Prośby pospolite o potrzeby zboru krześciańskiego powtórzył on za wspomnianym już katechizmem królewieckim lub za katechizmem nieświeskim (oba druki z około 1563 r.) ${ }^{113}$. Przypominają one naukę o Kościele powszechnym zjednoczonym Duchem Świętym, czyli o Zborze „po wszystkim świecie wszędy rozsypanym, w którym prawa a zbawienna nauka Syna [Bożego] brzmi i jest zachowana bez wszystkich przysad, omylnych rozumów ludzkich”. Kierowana dalej do Najwyższego modlitwa, aby oddalił ze swego Kościoła fałszywych pasterzy, a przydał pobożnych, zdaje się być refleksem walki z antytrynitarzami ${ }^{114}$.

W rozdziale kancjonału pt. Pieśni o zborze świętym znajdujemy przypomnienie nauki o Kościele Chrystusowym, który zastąpił Synagogę Izraela. Kościół jest oblubienicą Pana, a Ten króluje w nim przez swe Słowo ${ }^{115}$, Duch Święty zaś oznajmia oblubienicy - Kościołowi - jego powinności. Nie jest to oczywiście myśl oryginalna, gdyż o Kościele - niepokalanej oblubienicy Chrystusa, rządzonej i wzmacnianej Duchem - nauczał już Ulrich Zwingli w 1523 r., choć tu mamy zapewne jednak do czynienia z inspiracją głównie nauką Kalwina ${ }^{116}$. Teksty te znane były natomiast polskim

s. 296 (o krytyce Kalwina względem „Kościoła świętych” głoszonego przez anabaptystów).

112 [S. Sudrowiusz], Katechism albo krotkie w iedno mieysce zebranie wiary y powinnosći Krześciańskiey, wyd. 1, Wilno 1581. Korzystałem z egzemplarza BJ pozbawionego karty tytułowej (sygn. Cim. 901), datowanego na 1600 r. przez autorów Catalogus librorum saeculi XVI qui in Bibliotheca Iagellonica Cracoviensi asservantur, t. 4, cur. M. Malicki et al., Baden-Baden 2003 (Bibliotheca Bibliographica Aureliana), s. 303. M. A. Korzo (W sprawie, s. 179) omówiła różnice między krakowskim egzemplarzem a wydaniami z lat 1594 i 1600. Ponadto sięgnąłem do tego ostatniego wydania (BK, sygn. Cim. 0.341) oraz do edycji z $1594 \mathrm{r}$. (Biblioteka Uniwersytetu w Uppsali, sygn. Obr. 65:232; mkf BN 35481).

113 [Kancjonat], k. C viii ver.-C ix rec.; por. A. Kawecka, op. cit., s. 128-129.

114 [S. Sudrowiusz], op. cit., k. $\mathrm{C}_{4}$ ver.- $\mathrm{C}_{5}$ ver.

115 Ibidem, k. I xviii ver.

116 Por.: E. Campi, op. cit., s. 292-294; P. D. L. Avis, The Church in the Theology, s. 46; V.-M. Kärkkäinen, op. cit., s. 53-54. 
i litewskim ewangelikom przynajmniej od początku lat sześćdziesiątych wieku XVI ${ }^{117}$.

Kościół porównany został do „nowej winnicy”, zasadzonej w miejscu „winnicy Izraela”, przeniesionej przez Pana z Egiptu, ale, ponieważ „ciernia namnożyła”, zastąpił ją inną i poświęcił krwią Zbawiciela. Silnie podkreśla się realizację nowotestamentowej zapowiedzi o Chrystusie mieszkającym pośród owiec, dającym im bezpieczeństwo przed żywiołami, jak niegdyś arka Noego. Kościół stanowi kontynuację gmin chrześcijańskich czasów apostolskich. Expressis verbis wyrażone jest poczucie zagrożenia ze strony wrogiej większości, ale także świadomość bycia owczarnią Pana, którą broni przed antychrystem. „Małe stadko” (Łk 12, 32) posłusznie przyjmuje prześladowania jako zasłużony dopust Boży i jednocześnie, silne „pewną wiarą”, ufa w opiekę Chrystusa ${ }^{118}$. Taki obraz oblężonej wspólnoty konsekwentnie broniącej prawdziwej nauki Chrystusowej spotykamy w innych ówczesnych kolekcjach hymnów ewangelickich, od Pieśni duchownych a nabożnych Jana Seklucjana (1547) oraz Pieśni chwat boskich (1558) Jana Zaremby poczynając ${ }^{119}$. Wyprzedzając ich systematyczną analizę, która uwzględnić winna m.in. tradycję męczeństwa pierwszych chrześcijan, późnośredniowiecznej religijności pasyjnej oraz wpływ hymniki luterańskiej ${ }^{120}$, zauważyć wypada, że wyrażane pieśnią poczucie zagrożenia oraz oczekiwanie pocieszenia $\mathrm{w}$ godzinie próby nabierało aktualności w ówczesnych społecznych realiach. Nie zaskakuje więc, że Krzysztof Kraiński nie tylko powtórzył (z pewnymi zmianami)

117 A. Kawecka, op. cit., s. 129, 132-133; [Kancjonat], k. H i ver.-H v rec. O innym przedruku tych pieśni, datowanym na 1564 r., zob. M. Malicki, Nieznany dotychczas polski katechizm kalwiński ze zbiorów Biblioteki Księcia Augusta w Wolfenbüttel, „Biuletyn Biblioteki Jagiellońskiej”, 43, 1993, s. 52-53, 58.

118 [S. Sudrowiusz], op. cit., k. C 6 ver.-C 7 rec., K i-K vi.

119 S. Rospond, Wstęp, w: Jan Seklucjan, s. xxii-xxiii; J. Seklucjan, Pieśni duchowne a nabożne, Królewiec 1547 (BN, sygn. SD XVI.O.6249 adl.), s. 92-93; J. Zaremba, Pieśni chwat boskich, wyd. B. Brzezińska, A. Kawecka-Gryczowa, Kraków-Warszawa 1989 (Monumenta Musicae in Polonia. Seria B, Collectanea Musicae Artis), s. 8-9; P. Artomiusz, Cantional albo pieśni duchowne, Toruń 1587 (BCz, sygn. Cim. 1579 I), k. I 13-K 16.

120 Zakres takich studiów przybliża J. Z. Lichański, Pieśni kancjonatowe-problemy atrybucyjne i redakcyjne. Wybrane przyktady z tzw. Kancjonatu mazurskiego, w: Staropolska literatura dewocyjna. Gatunki, tematy, funkcje, red. I. M. Dacka-Górzyńska, J. Partyka, Warszawa 2015 (Staropolskie Teksty Paraliterackie, t. 3), s. 102-116. 
Pieśni o Kościele w swym kancjonale, ale także opatrzył je komentarzami argumentującymi wagę tych strof dla jego Kościoła ${ }^{121}$.

W podobnym klimacie utrzymane są Pieśni o świętej cerkwi wchodzące w skład kancjonału Walentego z Brzozowa, ogłoszonego w 1554 r. oraz - w zmienionej wersji - w 1569 r. pod auspicjami Jednoty Braci Czeskich. Kościół jawi się jako wspólnota, „święte miasto”, „utwirdzenie prawdy”, której głową i „opoką” jest Jezus, a „małe stadko Krysta posłuszne”, „maluczkie stadko” umacnia jedność wiary, łaski i nadziei ${ }^{122}$. Przedwiecznie wybrani stają się nowym stworzeniem w Chrystusie przez Słowo, świętą społecznością ochrzczonych krwią Zbawiciela, którą po cierpieniach doczesnych czeka nagroda oglądania Stwórcy w niebie. Poza Kościołem nie ma zbawienia, gdyż w nim wyznawana jest wiara i przyjmowane są sakramenty „ku pewności grzechów odpuszczenia i żywota nawrócenia”, „ku pożywaniu zbawienia, grzechów odpuszczenia"123. Jest to stanowisko podzielane przez luteranów, pod których wpływem bracia pozostawali. Nie ma tu też sprzeczności $\mathrm{z}$ nauką ewangelicko-reformowaną ${ }^{124}$. Zgodne $\mathrm{z}$ nią jest też przeświadczenie, że tylko Bóg swą łaską może wybawić człowieka od wiecznego potępienia, które za sprawą pierwszych rodziców stało się dziedzictwem rodzaju ludzkiego. Obok sakramentów i Słowa wymieniona została władza kluczy, co mogło być inspirowane naukami Lutra i Melanchtona ${ }^{125}$.

121 K. Kraiński, Kancyonat abo pieśni duchowne, [Wilno 1604]; wg A. Kaweckiej-Gryczowej, Wstęp, w: J. Zaremba, Pieśni, s. 10] (BJ, destrukt, sygn. 311276), k. F ix rec. $-F$ xxxiii rec.

122 Walenty z Brzozowa, Cantional albo ksiegy chwat Boskych, Królewiec 1554 (BO, sygn. 4047), k. F I ver.-F II; [idem], Cantional abo piesni duchowne, [Kraków] 1569 (BCz, sygn. Cim. 1564 I), s. 156-157. Szerzej o tych drukach zob.: A. Kawecka, Polskie kancjonaty protestanckie $w w$. XVI, mps w Archiwum UJ, sygn. WF II 505, s. 62-124; J. Dworzaczkowa, Bracia czescy w Wielkopolsce w XVI i XVII wieku, Warszawa 1997, s. 43; K. Zwanepol, The Structure and Dynamics of Luther's Catechism, „Acta Theologica”, 31, 2011, s. 400-401; M. A. Korzo, „Spis tento Otázek trojiech” Eukasza z Pragi. Przyczynek do historii katechizmów braci czeskich $i$ ich roli $w$ piśmiennictwie polskim (XVI wiek pierwsza potowa XVII stulecia), „Res Historica”, 35, 2013, s. 110, passim.

123 Walenty z Brzozowa, Cantional albo ksiegy, k. F IIver., F Xrec.; idem, Cantional abo piesni, s. $157,163$.

124 Sakrament aktem inkorporacji człowieka w Chrystusa, zob. S. Piwko, op. cit., s. 137-142; D. J. Smit, Calvin on the Sacraments and Church Unity, „In die Skriflig", 3, 2010, s. 254-263.

125 Walenty z Brzozowa, Cantional albo ksiegy, k. F I rec.-F XII; idem, Cantional abo piesni, s. $156-177$. 
Systematyczny wykład czeskobraterskiej nauki o Kościele przedstawił w 1585 r. przywódca Jednoty Szymon T. Turnowski ${ }^{126}$. W zestawieniu z poglądami na Kościół wyrażonymi w kancjonale Walentego z Brzozowa stanowisko konseniora wielkopolskiego ilustruje, skądinąd dobrze znaną, ewolucję nauki Jednoty w kierunku ewangelicyzmu reformowanego. Analogią do „bojującego” Kościoła ziemskiego ewangelików reformowanych jest tu Kościół „żołnierzujący”, jego dopełnieniem - tryumfujący, niebiański Zbór. Kościół powszechny wywodzi się z Kościoła starozakonnych patriarchów i proroków, Kościoła Doktorów oraz „zniewolonego pod antychrystowym jarzmem” ${ }^{27}$. Jest to więc pogląd bliski koncepcji Łaskiego ${ }^{128}$. Kościół ten gromadzi wszystkich wybranych przez wieki, odznacza się jednym ciałem, króluje w nim Chrystus-oblubieniec. Wśród podstawowych znaków widzialnego Kościoła wymienione zostały, podobnie jak w inspirowanym kalwinizmem Wyznaniu z 1575 r.: ewangeliczna nauka, sakramenty oraz dyscyplina ${ }^{129}$. Turnowski poświęca wiele miejsca kwestii, czy Kościół może błądzić.

Przedstawione wyżej poglądy dobrze odzwierciedlają więc ówczesną eklezjologię polskich i litewskich ewangelików ujętą w Konfesji sandomierskiej i propagowaną przez kaznodziejów ${ }^{130}$.

Wnioski

Wbrew ukazanym wyżej konfesyjnym narracjom, eklezjologie katolicka i ewangelicka pozostawały w bliskim związku - nie tylko dlatego, że budowane były na Biblii oraz wzajemnej krytyce. Zarówno katolicy, jak protestanci zgadzali się co do tego, że głową wspólnoty prowadzonej przez Ducha Świętego jest Chrystus, wierni są jej ciałem. Człowiek korzysta z zasługi męki i krzyżowej śmierci Jezusa, a więc z łaski Boga, poprzez sakramenty. Wspólnota Kościoła gromadzi

126 Poznaczenie krotkie niektórych questiy o Kościele Bożym, b.m. i r.w. (BK, sygn. Cim. 2642).

127 Ibidem, fol. Arec.-Aver.

128 Por. H. Kowalska-Kossobudzka, Jana Easkiego pojęcie, s. 87.

129 Nie jest to jednak ścisłe stanowisko Kalwina, por. wyżej, przyp. 100; szerzej zob.: J. Pelikan, Reformacja Kościota i dogmatów (1300-1700), Kraków 2010 (Tradycja Chrześcijańska. Historia Rozwoju Doktryny, t. 4), s. 262; H. Gmiterek, Bracia czescy a kalwini w Rzeczypospolitej: potowa XVI - potowa XVII wieku. Studium porównawcze, Lublin 1987, s. 94-97; M. A. Korzo, „Spis utento Otázek trojiech", s. 120-122.

130 O tym szerzej w: R. Czyż, Obrona wiary w edycjach postylli Grzegorza z Zarnowca, Warszawa 2008, s. 153-161. 
dobrych i złych, i w niej, według nakazów Ewangelii, formuje się moralność wiernych ${ }^{131}$. Kościół widzialny i niewidzialny stanowią jedność i nie ma poza nim zbawienia, dlatego definicja Stanisława Hozjusza ma wymowę uniwersalną i warto ją w tym miejscu zacytować:

Ecclesia porro catholica ibi est, ubi est fides catholica. Fides autem catholica ea est, quæ per orbem universum iuxta Christi præceptum eadem semper annunciatur, nec vel tempore, vel locis unquam variatur: a qua siquis dissentiat, is catholicus non est, quo singularem quandam opinionem, non unam communem omnium fidem complecti videtur ${ }^{132}$.

Ustalenia soboru trydenckiego rozwiewały wszelkie wątpliwości i choć Hozjusz powtarzał za Augustynem, że to miłość własna dzieli chrześcijan ${ }^{133}$, istotę niezgody celnie ujął Jakub Ledesma SI, zwięźle definiując Kościół jako „wszystko zebranie wiernych chrześcijanów, którzy się trzymają i wyznawają Pana Chrystusa, którego Kościoła głową jest sam Pan Chrystus a papież jego vicarius, to jest namiestnik na ziemi" 134 .

Dziedzictwo późnośredniowiecznych sporów wokół problemu jedności Kościoła ${ }^{135}$ nolens volens przejmowali protestanci. Daje temu świadectwo Krzysztof Kraiński, gdy w swych komentarzach do pieśni przywołuje stosowne pisma Augustyna, Ambrożego, Bernarda z Clairvaux. Nie ma wątpliwości, że „prawdziwy” Kościół to

131 Rozczarowanie w tym względzie praktyką nowych wspólnot wyznaniowych prowadziło do ich kontestacji, a przykładem tego była działalność Kaspara Schwenckfelda, zob.: G. Wąs, Kaspar von Schwenckfeld. Myśl i dziatalność do 1534 roku, Wrocław 2005 (Acta Universitatis Wratislaviensis. Historia, nr 129), s. 123-126, passim; A. Seguenny, W poszukiwaniu prawdziwej wiary. Szkice z historii religii XVI wieku: humanizm, reformacja, spirytualizm, Lublin 2009, s. $107-108$.

132 „Kościół katolicki sięga tak daleko, jak sięga wiara katolicka. Wiara katolicka zatem to taka, która wobec całego świata ściśle trzyma się zaleceń Chrystusowych i trwa niezależnie od miejsca lub czasu. Katolikiem nie jest ten, którego zdanie różniłoby się nawet w drobnym szczególe - nie jest on uznany za należącego do wspólnoty wiary”, S. Hozjusz, Confessio, k. 30ver.

133 Zob. S. Kozakiewicz, Stanistawa Hozjusza nauka o zbawieniu w Kościele katolickim: rozwój wybranych aspektów eklezjologicznych i soteriologicznych myśli Hozjusza $w$ relacji do osiagnięć teologii wspótczesnej, Olsztyn 2013 (Biblioteka Wydziału Teologii Uniwersytetu Warmińsko-Mazurskiego w Olsztynie, nr 82), s. 210-212.

134 Nauka chrześcijańska abo katechizmik dla dziatek przez Jakuba Ledezma, Kraków b.r.w. (BCz, sygn. Cim. 2462 I), k. 12rec.-12ver.

135 O tym szeroko J. Pelikan, op. cit., s. 85-155; S. Świeżawski, op. cit., s. 46-56. 
wspólnota wybranych i przejrzanych, „którzy nigdy zginąć nie mogą”. Jednak choć Kościół rzymski „skażony i zepsowany jest, jako w wierze, tak i w obyczajach”, to pozostaje zborem, choć „złym”. Należy jednak prosić Boga, aby przywiódł nieznających „prawej” nauki do „jednej owczarnie”"136. Gdy Paweł Gilowski i Krzysztof Trecy w przedmowie do postylli Grzegorza z Żarnowca kreślą bolesny obraz rozdartego i cierpiącego współczesnego im Kościoła, to jednocześnie przedstawiają go jako jeden dla wszystkich uznających Słowo prawdziwy Kościół powszechny ${ }^{137}$. Powtarzają więc opinię wyrażoną w Konfesji sandomierskiej, że nie wszyscy w Kościele powszechnym są członkami „prawdziwej społeczności świętej” 138 . Choć reformatorzy jednoznacznie sprzeciwiali się identyfikacji „,rzymskiej” konfesji z „prawdziwym” Kościołem, to nie odmawiali jej zwolennikom boskiej opieki ${ }^{139}$. Z trudem natomiast można doszukać się takich deklaracji w omawianych $\mathrm{w}$ artykule i pomieszczonych w kancjonałach pieśniach o Kościele ${ }^{140}$. Jak wspomniano, jedynym autorem katechizmu, który explicite dopuszczał możliwość poznania prawdziwej nauki poza własnym obozem konfesyjnym, w tym w Rzymie, był Seklucjan, choć również Mikołaj Rej akcentuje tu przepowiadanie Słowa. Drogi teologów obu obozów rozchodziły się w chwili, gdy przystępowali oni do interpretacji nowotestamentowych pryncypiów. Jednak niewykluczone, że świadomość takiego wspólnego fundamentu pomagała niektórym świeckim identyfikować swą religijność z pominięciem kontrastów doktrynalnych. Tak mogło być w Krakowie w drugiej połowie XVI i z początkiem XVII stulecia $^{141}$.

136 [Kancjonat], k. C xi ver.-C xii rec.; K. Kraiński, op. cit., k. F ix rec.-F xxviii rec.

137 Grzegorz z Żarnowca, Postilla albo wyktady ewanieliy niedzielnych, [Wilno] 1597 (BO, sygn. 51734), k. $A_{2}$ ver.-A 7 rec. O zbiorze tym szerzej w: J. T. Maciuszko, Ewangelicka postyllografia polska XVI-XVIII wieku, Warszawa 1987, s. 116-136; R. Czyż, op. cit., s. 12-33. O jednym i niepodzielnym Kościele w eklezjologii Kalwina zob. S. Piwko, op. cit., s. 122; D. J. Smit, op. cit., s. 247-269.

138 Konfesja sandomierska, s. 131-149.

139 Złożone zagadnienie stosunku reformatorów do katolickiej doktryny omawia P. D. L. Avis, por. idem, The Church in the Theology, s. 36-44. Stwierdza on (ibidem, s. 42), że "the Reformers can be found to say both that Rome is and is not the Church". Zob. też J. Pelikan, op. cit., s. 209.

140 Ich zdecydowanie i jednoznacznie antykatolicką wymowę podkreśla A. Kawecka, Polskie kancjonaty, s. 52, 71, 116.

141 W. Kowalski, Eschatologiczne poglady mieszkańców Krakowa doby reformacji, „Nasza Przeszłość”, 109, 2008, s. 5-34; por. J. T. Maciuszko, Bariery dialogu 
Szesnastowieczny Kościół rzymski odwoływał się do swego depozytu pamięci pokoleń, skąd płynąć miało przekonanie, że papież i hierarchowie to sukcesorzy apostołów. Według tej nauki autorytet Kościoła opierał się na Piśmie i Tradycji trwającej od czasów pierwszych chrześcijan. Ewangeliccy teolodzy przywoływali te same zdarzenia z dziejów nowotestamentowych, lecz w ich mniemaniu Tradycję niekłócącą się z Pismem poznawać można było co najwyżej w dziełach Ojców Kościoła ${ }^{142}$. Dla obu stron szczególnej aktualności nabierały komentarze Augustyna dokumentujące czasy obrony Kościoła przed fałszywymi interpretatorami Pisma. Różnice te znakomicie ilustruje refleksja Krzysztofa Kraińskiego:

Nie tak nowe rzeczy stawiamy, abyśmy stare psowali. Ale to, co widzimy być pożytecznego do budowania i do zachowania rządu jednoty świętej w domu Bożym, czynimy, przykładem doktorów świętych ${ }^{143}$.

Definicja Kościoła nie była tematem szczególnie dyskutowanym przez ewangelików polskich i litewskich, gdyż nie należała do zagadnień kontrowersyjnych, jak np. sakrament Stołu Pańskiego ${ }^{144}$. Znacznie trudniejsze zadanie stało przed wyjaśniającymi wiernym, dlaczego stanowią wspólnotę z chrześcijanami innych zborów i państw w Kościele powszechnym złączonym wiarą, której zasady były przedmiotem szczegółowych teologicznych dywagacji.

Do przyjęcia takiej, abstrakcyjnej dla przeciętnych audytorów, wiedzy potrzebna była siła wiary budowana komunikatywnym wykładem. W praktyce pastoralnej wykład taki sprowadzał się zapewne do wyliczenia błędów rzymskich i wyjaśnienia przyczyn ich odrzucenia ${ }^{145}$.

międzywyznaniowego w XVI i XVII wieku, w: Sztuka i dialog wyznań w XVI i XVII wieku, red. J. Harasimowicz, Warszawa 2000, s. 27-36.

142 K. Meller, op. cit., s. 191; R. Czyż, op. cit., s. 154-155.

143 K. Kraiński, Katechizm z naukami y pieśniami, Kraków 1609 (BJ, sygn. 311281), k. 5; zob. też S. H. Hendrix, Tradition and Authority in the Reformation, Aldershot 1996.

144 A. Kawecka-Gryczowa, op. cit., s. 228; szerzej na ten temat por.: U. Augustyniak, Konfesja sandomierska. Wstęp historyczny, Warszawa 1994, s. 20-25 oraz przykładowo D. Petkūnas, Wilno 1585 Colloquium - Lutheran and Reformed Discord over Sacramental Theology in Lithuania, OiRwP, 49, 2005, s. $17-34$.

145 Jak zapisano w wizytacji z 1582 r., poprzestawano raczej na nauce „rzeczy prostych”, zob. Akta synodów różnowierczych w Polsce, t. 3: Matopolska 1571-1632, oprac. M. Sipayłło, Warszawa 1983, s. 58, passim. O tym wspomniano też we wstępie do: [S. Sudrowiusz], op. cit., k. 5ver. 
Nauka ta, oparta przede wszystkim na negacji połączonej ze zwięzłym pouczeniem o jedności w wierze, nie tworzyła jednak obrazu, który skutecznie konkurowałby z wizją Kościoła powszechnego roztaczaną przez katolickich duchownych. Zakładając, że niedostatki wiedzy teologicznej i konieczność doskonalenia kaznodziejskiego warsztatu, nieraz od podstaw, na równi ograniczały efektywność perswazji przeciętnych księży, niezależnie od przynależności konfesyjnej, wypada uznać, że duchowni katoliccy byli w lepszej sytuacji. Kościoła powszechnego, o którym opowiadali, tłumacząc Credo, nie przedstawiali wyłącznie jako wyraźnie definiowanej wspólnoty zjednoczonych w prawdziwej wierze, ale raczej jako społeczności: świętych (spoglądających ze ścian kościołów), zmarłych (należało o nich pamiętać w modlitwie), starszych (przekazywali wiarę w skuteczność gestów i modlitw), wreszcie bywali w świecie, czyli np. w Krakowie, duchowi przewodnicy opowiadali o miłych Bogu papieżach i biskupach. Świadom tych pastoralnych realiów Benedykt Herbest trafnie ocenił możliwości przeciwnika w walce o dusze prostego ludu: „Bogobojnego chłopka zbijaj ty, którymi chcesz wykręty od prawej mądrości Kościoła Powszechnego, nic mu nie uczynisz, kacerzu"146. O słuszności tych przewidywań zwolennicy „prawdziwej” wiary boleśnie przekonywali się na co dzień. Według świadectwa Józefa Konarzewskiego, archidiakona włocławskiego, poddani jego sąsiada, kalwinisty Hieronima Rzeszowskiego, właściciela peryferyjnego małopolskiego Kosowa, upraszali księdza o posługę duszpasterską. Wypytywani przy tej okazji, nie byli w stanie powiedzieć, czego nauczał ich zatrudniony przez Rzeszowskiego ewangelicki minister, wspomagany w tym wysiłku przez samego pana wsi ${ }^{147}$.

Taka żarliwość i obojętność religijna nie należały do wyjątkowych. $\mathrm{Z}$ pewnością polskich ewangelików charakteryzowała świadomość przynależności do Kościoła powszechnego, „domu Boga żywego, zbudowanego z żywych i duchowych kamieni, na skale nieruchomego"148. Świadectwem tego są niektóre testamenty krakowskie spisane w kolejnych latach ${ }^{149}$. Postyllografia ewangelicka oraz znana nam praktyka zborowa wskazują jednak, że duszpasterze koncentrowali się raczej na

146 B. Herbest, op. cit., k. 89rec.

147 Catholici et sectarii concertatio, k. $\mathrm{A}_{\mathrm{iv}}$ ver.-B rec., Cver.- $\mathrm{C}_{\mathrm{ii}}$ rec., $\mathrm{C}_{\mathrm{iv}}$ rec.-Drec.; zob. też szerzej W. Urban, Chtopi wobec reformacji $w$ Matopolsce $w$ drugiej potowie XVI w., Kraków 1959, s. 136-139.

148 Konfesja sandomierska, s. 136.

149 W. Kowalski, op. cit., s. 14-16. 
tłumaczeniu „gruntu wiary prawdziwej a żywej”150. „Szczyra wiara”, wspierana plastycznymi opisami królestwa „rzymskiego Belzebuba” ${ }^{151}$, nie zawsze jednak wytrzymywała konfrontację z tym, co oglądano w Wiecznym Mieście. Ludwik Kromer, rajca krakowski, który przed 1575 r. odwiedził Rzym, przyznawał po latach:

aczkolwiek i w Krakowie niejakie nabożeństwo panuje, choć nie tak gwałtowne jałmużny i miłosierne uczynki, jednak nie mniej obfite owoce i lekarstwa darów duchownych, skarby nieprzebrane niebieskie. Nie mniej kaznodzieje nader wyborne i nauczyciele znamienite. Widząc taką świątobliwość, miłosierdzie, o zbawieniu ludzkim takie staranie, rad nie rad, przyznać musiałem, że to jest owczarnia onego Dobrego Pasterza. Tamże kajawszy się zbłąkania mego, z łaską Tego, który nie chce śmierci grzesznika, nawróciłem się do tej drogi, w której trwając do końca, wierzę pewnie, że się przy obietnicy Pańskiej i nadziei mojej nieomylnej zostoję $e^{152}$.

Język analizowanych tu tekstów, choć zawsze jednoznacznie i dosadnie określa przeciwnika według ówczesnych kategorii dobra i zła, rzadko kiedy jest agresywny, nigdy zaś rubaszny i krotochwilny, jak w antykatolickich utworach Reja czy Marcina Krowickiego ${ }^{153}$. W ówczesnej sytuacji społecznej bujny rozwój literatury polemicznej o charakterze wybitnie praktycznym, do którego to nurtu należą katechizmy, był nieunikniony. Powyższe obserwacje prowadzą jednak do wniosku, że w szerszej skali teologia kontrowersyjna, dominująca w ówczesnym nauczaniu religijnym, przynosiła więcej szkody niż pożytku w propagowaniu wiedzy o relacjach miedzy Bogiem a człowiekiem $^{154}$.

150 Akta synodów, t. 3, s. 57-68; J. T. Maciuszko, Ewangelicka postyllografia, s. 29-148.

151 Catholici et sectarii concertatio, $\mathrm{k} . \mathrm{A}_{\mathrm{iii}}$ rec.-B rec.

152 L. Kromer, op. cit., k. nlb. Autora wzmiankuje Z. Noga, Urzędnicy miejscy Krakowa, cz. 2: 1500-1794, Kraków 2008 (Spisy urzędników miejskich z obszaru dawnej Rzeczypospolitej, Śląska i Pomorza Zachodniego, t. 3, z. 1), wg indeksu.

153 Zob. M. Czapska, Polemika religijna pierwszego okresu reformacji w Polsce, „Reformacja w Polsce”, 5/19, 1928, s. 3, passim.

154 Por. F. Bracha, op. cit., s. 125; zob. też J. T. Maciuszko, Ewangelicka postyllografia, s. 148 (o „retoryce sporu” w twórczości Gilowskiego). 


\section{Bibliografia}

\section{Źródła drukowane}

Antoni z Napachania, Enchiridion to iest ksiaszki ręczne o nauce Chrześcianskiey, czego się Chrześciański cztowiek dzierżeć ma czasu ninieyszey rozności wiary, Kraków 1558

P. Artomiusz, Cantional albo pieśni duchowne, Toruń 1587

M. Białobrzeski, Katechizm albo wizerunk prawey wiary chrześciańskiej wedle nauki Pana Jezusa Chrystusa, Apostotów iego y Kościota iego świętego przeciwko wszytkim obtędliowościam tych czasów barzo pożyteczny, Kraków 1566

Catechismus to jest zupetna nauka chrzésicianska przez Jana Brenciusza z pisma prorockiego i apostolskiego zniesiona, ktory możesz dobrze mata Bibliq nazwać, Królewiec 1556

Catholici et sectarii concertatio, Cracoviae 1569

P. Gilowski, Wyktad katechizmu Kościota krześcijańskiego, Kraków 1579

Grzegorz z Żarnowca, Postilla albo wyktady ewanieliy niedzielnych, [Wilno] 1597

B. Herbest, Nauka prawego chrzésijanina, Kraków 1566

S. Hosius, Confessio catholicae fidei christiana: vel potius explicatio quaedam confessionis, in synodo Petricoviensi factae M.D.LI., Antverpiae 1561

[Kancjonat], Królewiec 1563

L. Kromer, Przedmowa, w: L. Lessius, Narada, której wiary trzymać się mamy, Kraków 1616

K. Kraiński, Kancyonat abo pieśni duchowne, [Wilno 1604]

K. Kraiński, Katechizm z naukami y pieśniami, Kraków 1609

J. Ledesma, Nauka chrześcijańska abo katechizmik dla dziatek, Kraków b.r.w.

A. Novicampianus, Scopus biblicus Veteris et Novi Testamenti, cum annotationibus summam doctrinae Christianae complectentibus, wyd. 1, Cracoviae 1553, wyd. 3, Antverpiae 1559

H. Powodowski, Catechizm Kościota Powszechnego, nauki do zbawienia potrzebnieysze, z dowodow Pisma świętego snadna, a doktadna króthkością zamykajacy [- -] ksiażki bardzo pożyteczne [- -], Poznań 1577

Poznaczenie krotkie niektórych questiy o Kościele Bożym, b.m. i r.w.

[M. Rej], Catechismus to jest nauka barzo pożyteczna każdemu wiernemu krześijaninowi jako się ma $w$ zakonie Bożym a w wierze i w dobrych uczynkach sprawować, wyd. 2, Kraków [1548 lub 1549]

J. Seklucjan, Catechismus to iest krotka a prosta (starey wiary chrzesciańskiey) nauka powtore wydana, Królewiec 1549

J. Seklucjan, Catechismus to iest nauka naprzednieisza y potrzebnieisza ku zbawyenyu o wierze krzescianskiej, Królewiec 1547

J. Seklucjan, Pieśni duchowne a nabożne, Królewiec 1547

[S. Sudrowiusz], Katechism albo krotkie w iedno mieysce zebranie wiary y powinności Krześciańskiey, wyd. 1, Wilno 1581 (i następne z lat 1594-1600) 
[Walenty z Brzozowa], Cantional abo piesni duchowne, [Kraków] 1569

Walenty z Brzozowa, Cantional albo ksiegy chwat Boskych, Królewiec 1554

Wydawnictwa źródłowe

Akta synodów różnowierczych $w$ Polsce, t. 3: Matopolska 1571-1632, oprac. M. Sipayłło, Warszawa 1983

Catechismus to jest nauka barzo pożyteczna każdemu wiernemu krzésijaninowi, jako się ma w zakonie Bożym a w wierze i $w$ dobrych uczynkach sprawować: 1543 r., wyd. F. Pułaski, Kraków 1910 (Biblioteka Pisarzów Polskich, nr 56)

Dokumenty soborów powszechnych. Tekst taciński i polski, t. 4: 1511-1870: Lateran, Trydent, Watykan I, oprac. A. Baron, H. Pietras, Kraków 2005

Druki mazurskie XVI w., wyd. S. Rospond, Olsztyn 1948

S. Hozjusz, Chrześcijańskie wyznanie wiary katolickiej albo Wyjaśnienie wyznania ztożonego przez ojców zebranych na synodzie prowincjonalnym, który odbyt się w Piotrkowie roku pańskiego tysięcznego pięćsetnego pięćdziesiątego pierwszego, w miesiacu maju [z mogunckiego wyd. roku 1557], tł. J. Wojtkowski, Olsztyn 1999

Katechizm brzeski, wyd. F. Pułaski, Warszawa 1908 (Collectanea Biblioteki Ordynacji hr. Krasińskich, nr 1)

Konfesja sandomierska. Transkrypcja i komentarz jezykowy, oprac. K. Długosz-Kurczabowa, Warszawa 1995

J. Seklucjan, Wybór pism, oprac. S. Rospond, Olsztyn 1979

J. Seklucjan, Wyznanie wiary chrześcijańskiej, oprac. H. Kowalska, S. Rospond, Warszawa 1972 (Biblioteka Pisarzy Reformacyjnych, nr 10)

J. Zaremba, Pieśni chwat boskich, wyd. B. Brzezińska, A. Kawecka-Gryczowa, Kraków-Warszawa 1989 (Monumenta Musicae in Polonia. Seria B, Collectanea Musicae Artis)

\section{Literatura}

U. Augustyniak, Konfesja sandomierska. Wstęp historyczny, Warszawa 1994

P. D. L. Avis, The Church in the Theology of the Reformers, Eugene (OR) 2002

P. D. L. Avis, Luther's Theology of the Church, „Churchman”, 97, 1983

J. Becker, Migration and Confession among Sixteenth-Century Western European Reformed Christians, „Reformation and Renaissance Review”, 13, 2011

K. Bem, "From Many Different Sources”. The Formation of the Polish and Lithuanian Reformed Liturgy, w: Liturgy in Migration. From the Upper Room to Cyberspace, ed. by T. Berger, Collegeville 2012

F. Bracha, Jakub Wujek jako dogmatyk, „Polonia Sacra”, 3/1-2, 1950

K. Bracha, Nauczanie kaznodziejskie w Polsce późnego średniowiecza. Sermones dominicales et festivales z tzw. kolekcji Piotra z Mitostawia, Kielce 2007 
M. Brzozowski, Biatobrzeski Marcin OCist, w: Encyklopedia katolicka, t. 2, red. F. Gryglewicz et al., Lublin 1995

S. Bylina, Chrystianizacja wsi polskiej u schytku średniowiecza, Warszawa 2002

E. Campi, Calvin's Understanding of the Church, „Reformed World”, 57, 2007

Catalogus librorum saeculi XVI qui in Bibliotheca Iagellonica Cracoviensi asservantur, t. 4, cur. M. Malicki et al., Baden-Baden 2003 (Bibliotheca Bibliographica Aureliana)

P. Chaunu, Czas reform. Historia religii i cywilizacji (1250-1550), tt. J. Grosfeld, Warszawa 1989

M. Czapska, Polemika religijna pierwszego okresu reformacji w Polsce, „Reformacja w Polsce", 5/19, 1928

R. Czyż, Obrona wiary w edycjach postylli Grzegorza z Żarnowca, Warszawa 2008

D. P. Daniel, Luther on the Church, w: The Oxford Handbook of Martin Luther's Theology, ed. by R. Kolb, I. Dingel, L. Batka, Oxford 2014

A. Dąbrówka, Treści religijne w średniowiecznych podręcznikach i lekturach szkolnych, w: Animarum cultura. Studia nad kultura religijna na ziemiach polskich w średniowieczu, t. 1: Stosunki kościelno-publiczne, red. H. Manikowska, W. Brojer, Warszawa 2008 (Colloquia Mediaevalia Varsoviensia, t. 4)

J. Dworzaczkowa, Bracia czescy w Wielkopolsce w XVI i XVII wieku, Warszawa 1997

J. Dworzaczkowa, Z dziejów Braci Czeskich w Polsce, Poznań 2003

P. Fijałkowski, Kancjonat Piotra Artomiusza z 1620 r., OiRwP, 44, 2000

H. Gmiterek, Bracia czescy a kalwini w Rzeczypospolitej: potowa XVI - potowa XVII wieku. Studium porównawcze, Lublin 1987

M. J. Haemig, The Influence of the Genres of Exegetical Instruction, Preaching and Catechesis on Luther, w: The Oxford Handbook of Martin Luther's Theology, ed. by R. Kolb, I. Dingel, L. Batka, Oxford 2014

M. Hanusiewicz-Lavallee, Okrucieństwo kacyrskie przeciw katolikom w Anglijej, czyli polski gtos $w$ sporze o męczeństwo, OiRwP, 56, 2012

S. H. Hendrix, Tradition and Authority in the Reformation, Aldershot 1996

A. Januszek-Sieradzka, W co wierzyt król Zygmunt August?, w: Rycerze, wędrowcy, kacerze. Studia z historii średniowiecznej $i$ wczesnonowożytnej Europy środkowej, red. B. Wojciechowska, W. Kowalski, Kielce 2013

V.-M. Kärkkäinen, An Introduction to Ecclesiology. Ecumenical, Historical and Global Perspectives, Downers Grove (Ill.) 2002

Katalog poloników XVI wieku Biblioteki Jagiellońskiej, t. 1: A-E, red. M. Malicki, E. Zwinogrodzka, oprac. M. Gołuszka et al., Warszawa-Kraków 1992

A. Kawecka, Kancjonaty protestanckie na Litwie w w. XVI, „Reformacja w Polsce", 4, 1926 
A. Kawecka, Polskie kancjonaty protestanckie $w w . X V I$, mps w Archiwum UJ, sygn. WF II 505

A. Kawecka-Gryczowa, Spory o „szczyra prawde”, OiRwP, 23, 1978

R. Keen, Political Authority and Ecclesiology in Melanchthon's De ecclesiae autoritate, „Church History”, 65, 1996

A. Kiciński, Kierunki rozwoju katechizmów katolickich, „Roczniki Pastoralno-Katechetyczne", 59, 2012

Y. Kim, The Identity and the Life of the Church. John Calvin's Ecclesiology in the Perspective of his Anthropology, Eugene 2014

R. M. Kingdon, The Church. Ideology or Institution, „Church History”, 50, 1981

K. Kolbuszewski, Postyllografia polska XVI i XVII w., Kraków 1921

J. J. Kopeć, Nurt pasyjny w średniowiecznej religijności polskiej, w: Męka Chrystusa wczoraj i dziś, red. H. D. Wojtyska, J. J. Kopeć, Lublin 1981

M. Korzo, Polski przektad katechizmu Jakuba Ledesmy TJ i jego wptyw na tradycje unicka $w$ XVII $w$., OiRwP, 47, 2004

M. Korzo, Przyczynek do roli druków bazylejskich w XVI-wiecznym piśmiennictwie ewangelickim Wielkiego Księstwa Litewskiego, OiRwP, 55, 2011

M. A. Korzo, "Spis tento Otázek trojiech” Eukasza z Pragi. Przyczynek do historii katechizmów braci czeskich i ich roli w piśmiennictwie polskim (XVI wiek - pierwsza potowa XVII stulecia), „Res Historica”, 35, 2013

M. Korzo, W sprawie jednego zXVI-wiecznych katechizmów kalwińskich $w$ Rzeczpospolitej, OiRwP, 52, 2007

M. Kosman, Protestanci i kontrreformacja. $Z$ dziejów tolerancji $w$ Rzeczypospolitej XVI-XVIII wieku, Wrocław 1978

H. Kowalska, 'Przejrzani i wybrani'. O Kościele na Zgodzie Sandomierskiej budowanym, w: Kultura polska a kultura europejska. Prace ofiarowane Januszowi Tazbirowi $w$ sześśdziesiąta rocznice urodzin, red. M. Bogucka, J. Kowecki, Warszawa 1987

H. Kowalska-Kossobudzka, Jana Easkiego pojęcie Kościota, OiRwP, 10, 1965

H. Kowalska-Kossobudzka, Wptyw Jana Easkiego na ksztattowanie sie reformacyjnego Kościota w Matopolsce, w: Jan Easki 1499-1560. W pięćsetlecie urodzin, red. W. Kriegseisen, P. Salwa, Warszawa 2001

W. Kowalski, Eschatologiczne poglady mieszkańców Krakowa doby reformacji, „Nasza Przeszłość”, 109, 2008

S. Kozakiewicz, Stanistawa Hozjusza nauka o zbawieniu w Kościele katolickim: rozwój wybranych aspektów eklezjologicznych i soteriologicznych myśli Hozjusza $w$ relacji do osiagnięć teologii wspótczesnej, Olsztyn 2013 (Biblioteka Wydziału Teologii Uniwersytetu Warmińsko-Mazurskiego w Olsztynie, nr 82)

D. Kuźmina, Katechizmy w Rzeczypospolitej XVI i początku XVII wieku, Warszawa 2002

J. Kracik, Przeciw reformacji, w: Kościót krakowski w tysiacleciu, Kraków 2000 
R. Kuśmierczyk, Problematyka Listu pasterskiego kard. Jerzego Radziwitta z roku 1593, „Nasza Przeszłość”, 100, 2003

A. Lenartowicz-Zagrodna, Defensio verae translationis corporis Catechismi in linguam Polonicam, adversus calumnias Joannis Secluciani Jana Maleckiego - przektad wraz z komentarzem, „Poznańskie Studia Polonistyczne. Seria Językoznawcza”, 38, 2011

R. M. Leszczyński, Nauka ewangelicko-reformowana w polskojezycznych katechizmach z XVI wieku, w: Ewangelicyzm reformowany w pierwszej Rzeczypospolitej. Dialog z Europa $i$ wybory aksjologiczne $w$ świetle literatury i piśmiennictwa XVI-XVII wieku, red. D. Chemperek, Warszawa 2015 (Kultura Pierwszej Rzeczypospolitej w Dialogu z Europą. Hermeneutyka Wartości, t. 9)

J. Z. Lichański, Pieśni kancjonatowe - problemy atrybucyjne i redakcyjne. Wybrane przyktady z tzw. Kancjonatu mazurskiego, w: Staropolska literatura dewocyjna. Gatunki, tematy, funkcje, red. I. M. Dacka-Górzyńska, J. Partyka, Warszawa 2015 (Staropolskie Teksty Paraliterackie, t. 3)

B. Lugioyo, Martin Bucer's Doctrine of Justification. Reformation Theology and Early Modern Irenicism, Oxford-New York 2010 (Oxford Studies in Historical Theology)

J. T. Maciuszko, Bariery dialogu międzywyznaniowego w XVI i XVII wieku, w: Sztuka i dialog wyznań w XVI i XVII wieku, red. J. Harasimowicz, Warszawa 2000

J. T. Maciuszko, Ewangelicka postyllografia polska XVI-XVIII wieku, Warszawa 1987

J. T. Maciuszko, Mikotaj Rej. Zapomniany teolog ewangelicki z XVI w., Warszawa 2002

J. T. Maciuszko, Poglady religijne Mikotaja Reja, w: Mikotaj Rej z Nagtowic. W pięísetna rocznice urodzin, red. W. Kowalski, Kielce 2005

M. Malicki, Nieznany dotychczas polski katechizm kalwiński ze zbiorów Biblioteki Księcia Augusta w Wolfenbüttel, „Biuletyn Biblioteki Jagiellońskiej”, 43, 1993

P. Matheson, Martin Bucer and the Old Church, w: Martin Bucer. Reforming Church and Community, ed. by D. F. Wright, Cambridge-New York

K. Meller, „Noc przeszta, a dzień się przyblizyt”. Studia o polskim piśmiennictwie reformacyjnym XVI wieku, Poznań 2004

C. Mohrmann, Saint Jérôme et Saint Augustin sur Tertullien, „Vigiliae Christianae", 5, 1951

P. J. Naudé, Why is a Multiplicity of Confessions Particular to the Reformed Tradition?, „Acta Theologica”, 20, 2014

Z. Noga, Urzędnicy miejscy Krakowa, cz. 2: 1500-1794, Kraków 2008 (Spisy urzędników miejskich z obszaru dawnej Rzeczypospolitej, Śląska i Pomorza Zachodniego, t. 3, z. 1) 
E. Ozorowski, Powodowski (Povodovius, z Powodowa) Hieronim, w: SPTK, t. 3, red. H. E. Wyczawski, Warszawa 1983

L. Palmer Wandel, Reading Catechisms, Teaching Religion, Leiden-Boston 2015

W. Pawlik, Katechizmy w Rzeczypospolitej od XVI do XVIII wieku, Lublin 2010

J. Pelikan, Reformacja Kościota i dogmatów (1300-1700), Kraków 2010 (Tradycja Chrześcijańska. Historia Rozwoju Doktryny, t. 4)

D. Petkūnas, Wilno 1585 Colloquium - Lutheran and Reformed Discord over Sacramental Theology in Lithuania, OiRwP, 49, 2005

A. Pettegree, Reformation and the Culture of Persuasion, Cambridge 2007

S. Piwko, Jan Kalwin. Życie i dzieto, Warszawa 1995

S. Rabiej, Herbest, Herbestus Neapolitanus, Benedykt SJ, w: Encyklopedia katolicka, t. 4, red. J. Walkusz, Lublin 1993

S. Radoń, Z dziejów polemiki antyariańskiej w Polsce XVI-XVII wieku, Kraków 1993

M. Rechowicz, Antoni z Napachania, w: Encyklopedia katolicka, t. 1, red. F. Gryglewicz et al., Lublin 1995

T. Reroń, Katechizmy $w$ dobie Soboru Trydenckiego, „Wrocławski Przegląd Teologiczny", 7, 1999

A. Rojewski, Formacja duchowieństwa archidiakonatu dobrzyńskiego w latach 1597-1609 i jej wptyw na przyjęcie posoborowej liturgii, „Studia Płockie”, 4, 1976

M. Rożek, Katedra wawelska w XVII wieku, Kraków 1980 (Biblioteka Krakowska, nr 121)

S. E. Schreiner, Are you alone wise? The Search for Certainty in the Early Modern Era, Oxford-New York 2011

S. E. Schreiner, Church, w: The Oxford Encyclopedia of the Reformation, vol. 1, ed. by H. J. Hillebrand, Oxford-New York 1996

A. Seguenny, W poszukiwaniu prawdziwej wiary. Szkice z historii religii XVI wieku: humanizm, reformacja, spirytualizm, Lublin 2009

I. Skierska, Obowiazek mszalny w średniowiecznej Polsce, Warszawa 2003

A. Skolimowska, Confessio fidei Hozjusza jako podstawa katechizacji wiernych w Hiszpańskich Niderlandach, „Studia Warmińskie”, 43, 2006

R. Skrzyniarz, Powodowski Hieronim, w: Encyklopedia katolicka, t. 16, red. S. Wilk et al., Lublin 2012

J. Z. Słowiński, Katechizmy katolickie w jezyku polskim od XVI do XVIII wieku, Lublin 2005

D. J. Smit, Calvin on the Sacraments and Church Unity, „In die Skriflig”, 3, 2010

K. Smolarek, Piotr Artomiusz i jego kancjonat toruński z końca XVI wieku, „Rocznik Toruński”, 41, 2014 
W. van't Spijker, Bucer's Doctrinal Legacy as Formulated in his Last Three Wills and Testaments, „Reformation and Renaissance Review”, 3, 2001

S. Szczotka, Gilowski Pawet, PSB, 7, 1948-1958

S. Świeżawski, Eklezjologia późnośredniowieczna na rozdrożu, Kraków 1990

J. Tazbir, Szlachta i teologowie. Studia z dziejów polskiej kontrreformacji, Warszawa 1987

S. Tworek, Raków w okresie „nieustającego synodu” (1569-1572), w: Wokót dziejów i tradycji arianizmu, red. L. Szczucki, Warszawa 1971

J. Tyrawa, Nowopolczyk, Nowopolski, Novicampianus, Wojciech, w: Encyklopedia katolicka, t. 14, red. E. Gigilewicz et al., Lublin 2010

Universal Short Title Catalogue, ustc.ac.uk

W. Urban, Chtopi wobec reformacji w Matopolsce $w$ drugiej potowie XVI w., Kraków 1959

W. Urban, Reformacja w życiu wsi matopolskiej, w: Et haec facienda et illa non omittenda. Profesor Wactaw Urban $w$ swych dzietach wybranych, red. A. Kądziela et al., Warszawa 2012 (Opera Necessaria)

W. Urban, Z. Kłosińska, Klątwy przeciwko Rejowi, w: Et haec facienda et illa non omittenda. Profesor Wactaw Urban w swych dzietach wybranych, red. A. Kądziela et al., Warszawa 2012 (Opera Necessaria)

G. Wąs, Kaspar von Schwenckfeld. Myśl i dziatalność do 1534 roku, Wrocław 2005 (Acta Universitatis Wratislaviensis. Historia, nr 129)

N. Widok, Klemens Rzymski o sukcesji apostolskiej, „Vox Patrum”, 62, 2014

I. Winiarska, Stownictwo religijne polskiego kalwinizmu od XVI do XVIII wieku (na tle terminologii katolickiej), Warszawa 2004

T. Wiślicz, Zarobić na duszne zbawienie. Religijność chtopów matopolskich od potowy XVI do końca XVIII wieku, Warszawa 2001

B. Wojciechowska, Krytyka religijności katolickiej w pismach Mikotaja Reja, w: Mikotaj Rej z Nagtowic. W pięćsetna rocznice urodzin, red. W. Kowalski, Kielce 2005

B. Wojciechowska, Od godów do św. Łucji. Obrzędy doroczne w Polsce późnego średniowiecza, Kielce 2000

J. Wolny, $Z$ dziejów katechezy, w: Dzieje teologii katolickiej w Polsce, t. 1: Sredniowiecze, Lublin 1974

H. E. Wyczawski, Antoni z Napachania, w: SPTK, t. 1, red. H. E. Wyczawski, Warszawa 1981

H. E. Wyczawski, Biatobrzeski Marcin, w: SPTK, t. 1, red. H. E. Wyczawski, Warszawa 1981

H. E. Wyczawski, Biblioteki parafialne w diecezji krakowskiej u schytku XVI wieku, „Polonia Sacra”, 7, 1955

H. E. Wyczawski, Herbest (Herbestus, Neapolitanus) Benedykt, w: SPTK, t. 2, red. H. E. Wyczawski, Warszawa 1982

H. E. Wyczawski, Nowopolczyk Wojciech, w: SPTK, t. 3, red. H. E. Wyczawski, Warszawa 1983 
H. E. Wyczawski, Studia nad wewnętrznymi dziejami Kościota w Matopolsce na schytku XVI wieku, „Prawo Kanoniczne”, 7, 1964

K. Zwanepol, The Structure and Dynamics of Luther's Catechism, „Acta Theologica", 31, 2011

\section{"Verily, this is the sheepfold of that Good Shepherd": The Idea of the "True" Church in Sixteenth-century Polish Catechisms}

The article discusses how the notion of the Church was understood and explained by authors of sixteenth-century Polish Catholic and Evangelical catechisms. Teaching of the constitution of a church was a basic pastoral duty and part of the rudimentary knowledge provided to the faithful.

Six Catholic catechisms of the years 1553 to 1600 and thirteen Evangelical ones, which were published between 1543 and 1609, constitute the main source base, the latter manuals being penned under the influence of Luther, Melanchthon as well as South-German and Swiss theologians. Following the Tridentine programme, the Catholic authors present their Church as unified under the Pope's authority and the only inheritor of the works of the Apostles. The veracity of its teaching is testified to with God's unnatural interventions. The Protestant authors explain the basically coherent, relevant ideas of the Reformation's protagonists. They teach about "the visible and outward Church", which is manifested by all those congregations that are fed by God's pure Word, and where the sacraments are duly administered. There is also "the inward and invisible Church", which the faithful confess in the Credo. It comprises all disciples of Christ, who is the only head of His Church. Thus the teaching on the Church presented in the Evangelical sources that are employed belongs to the mainstream of sixteenth-century Protestantism and aptly illustrates the reception of Evangelical theologies in the Kingdom of Poland and in the Grand Duchy of Lithuania. In the analysed sources, arguments for the veracity of Church are always supplemented with the refutation of contradictory standpoints through reference to the Bible and the Church Fathers, mostly to Augustine.

Despite strong polemical tone, the Biblical grounds of the Church could contribute to communication and understanding between Christians of antagonistic denominations, and this could sometimes result in conversion. The explanation of ecclesiological rudiments was easier for Catholic clergy, who referred to tradition and emotions, while Evangelical pastors could not ignore the abstract concepts of the "veracity" and "spiritual connectedness" of Christians, which were more difficult to render to the laity. 
Prof. dr hab. Waldemar Kowalski, wykładowca Instytutu Historii Uniwersytetu Jana Kochanowskiego w Kielcach. Jego zainteresowania badawcze obejmują stosunki wyznaniowe, etniczne i dzieje Kościoła katolickiego w Polsce XV-XVIII w., emigrację z Wysp Brytyjskich do Europy Środkowej w XVI-XVII w., nauki pomocnicze historii, a szczególnie historię archiwów i kancelarii oraz epigrafikę. E-mail: kowalski@ujk.edu.pl. 